\title{
Deformation mechanisms in mafic amphibolites and granulites: record from the Semail metamorphic sole during subduction infancy
}

\author{
Mathieu Soret $^{1}$, Philippe Agard ${ }^{1}$, Benoît Ildefonse ${ }^{2}$, Benoît Dubacq ${ }^{1}$, Cécile Prigent $^{3}$, and Claudio Rosenberg ${ }^{1}$ \\ ${ }^{1}$ Sorbonne Université, CNRS-INSU, Institut des Sciences de la Terre Paris, ISTeP UMR 7193, 75005 Paris, France \\ ${ }^{2}$ Géosciences Montpellier, Université de Montpellier, CNRS, Université Antilles, CEDEX 05, 34095 Montpellier, France \\ ${ }^{3}$ Université Grenoble Alpes, Université Savoie Mont Blanc, CNRS, IRD, IFSTTAR, ISTerre, 38000 Grenoble, France
}

Correspondence: Mathieu Soret (math.soret@gmail.com)

Received: 6 February 2019 - Discussion started: 14 February 2019

Revised: 25 June 2019 - Accepted: 1 July 2019 - Published: 23 October 2019

\begin{abstract}
This study sheds light on the deformation mechanisms of subducted mafic rocks metamorphosed at amphibolite and granulite facies conditions and on their importance for strain accommodation and localization at the top of the slab during subduction infancy. These rocks, namely metamorphic soles, are oceanic slivers stripped from the downgoing slab and accreted below the upper plate mantle wedge during the first million years of intraoceanic subduction, when the subduction interface is still warm. Their formation and intense deformation (i.e., shear strain $\geq 5$ ) attest to a systematic and transient coupling between the plates over a restricted time span of $\sim 1 \mathrm{Myr}$ and specific rheological conditions. Combining microstructural analyses with mineral chemistry constrains grain-scale deformation mechanisms and the rheology of amphibole and amphibolites along the plate interface during early subduction dynamics, as well as the interplay between brittle and ductile deformation, water activity, mineral change, grain size reduction and phase mixing.

Results indicate that increasing pressure and temperature conditions and slab dehydration (from amphibolite to granulite facies) lead to the nucleation of mechanically strong phases (garnet, clinopyroxene and amphibole) and rock hardening. Peak conditions $\left(850^{\circ} \mathrm{C}\right.$ and $\left.1 \mathrm{GPa}\right)$ coincide with a pervasive stage of brittle deformation which enables strain localization in the top of the mafic slab, and therefore possibly the unit detachment from the slab. In contrast, during early exhumation and cooling (from $\sim 850$ down to $\sim$ $700{ }^{\circ} \mathrm{C}$ and $0.7 \mathrm{GPa}$ ), the garnet-clinopyroxene-bearing amphibolite experiences extensive retrogression (and fluid ingression) and significant strain weakening essentially ac-
\end{abstract}

commodated in the dissolution-precipitation creep regime including heterogeneous nucleation of fine-grained materials and the activation of grain boundary sliding processes. This deformation mechanism is closely assisted with continuous fluid-driven fracturing throughout the exhumed amphibolite, which contributes to fluid channelization within the amphibolites. These mechanical transitions, coeval with detachment and early exhumation of the high-temperature (HT) metamorphic soles, therefore controlled the viscosity contrast and mechanical coupling across the plate interface during subduction infancy, between the top of the slab and the overlying peridotites. Our findings may thus apply to other geodynamic environments where similar temperatures, lithologies, fluid circulation and mechanical coupling between mafic rocks and peridotites prevail, such as in mature warm subduction zones (e.g., Nankai, Cascadia), in lower continental crust shear zones and oceanic detachments.

\section{Introduction}

Metamorphic soles underlying ophiolites are 10-100 m thick metamorphosed oceanic slivers stripped from the slab during subduction infancy (Hacker, 1990; Dewey and Casey, 2013; Agard et al., 2016; Rioux et al., 2016; Guilmette et al., 2018). Their accretion to the upper plate mantle wedge (i.e., the future ophiolite; Fig. 1a) is indicative of the rheology of the nascent, still warm interface, which favors strong mechanical coupling between the two plates (Agard et al., 2016, 2018; Soret et al., 2016, 2017). Internal changes in lithologies and metamorphic conditions reveal short-lived, stepwise ac- 
cretion at characteristic pressure-temperature-time $(P-T-$ $t$ ) conditions (Wakabayashi and Dilek, 2000, 2003; Plunder et al., 2016; Soret et al., 2017): two major accretion events have been identified in the mafic, high-temperature amphibolite to granulite facies portions of the Semail ophiolite sole (Oman and United Arab Emirates, UAE) at $850 \pm 50^{\circ} \mathrm{C}$ and $0.9 \pm 0.2 \mathrm{GPa}$ and $750 \pm 50^{\circ} \mathrm{C}$ and $0.7 \pm 0.2 \mathrm{GPa}$ (Soret et al., 2017). The striking similarity of $P-T$ conditions across the whole ophiolite width $(\sim 150 \mathrm{~km})$ also indicates that these slivers experienced shear strains of at least 4-5 gamma during accretion/exhumation (Soret et al., 2017), coeval with large ductile deformation in the banded peridotites above (Boudier et al., 1988; Prigent et al., 2018a, c).

How deformation is accommodated within the amphibolebearing sole rocks and how mafic slivers get detached from the top of the subducting slab and accreted to the upper plate at $T \geq 700^{\circ} \mathrm{C}$ is so far unknown. To investigate the deformation mechanisms accompanying the progressive change in $P$ and $T$ conditions and mineralogy (i.e., essentially amphibole, with varying amounts of plagioclase, clinopyroxene and garnet), we provide detailed microstructural and mineral chemistry data from the well-constrained Semail ophiolite sole. In contrast to plagioclase and clinopyroxene (e.g., Bascou et al., 2002; Rybacki and Dresen, 2004; Hier-Majumder et al., 2005; Dimanov et al., 2007), the physical properties and mechanical behavior of amphibole and amphibolebearing polymineralic aggregates, commonly found over a large range of $P-T$ and water activity conditions, have been far less studied and remain puzzling (see Getsinger and Hirth, 2014). Understanding their deformation mechanisms is therefore expected to shed light on the plate interface rheology during subduction infancy (Soret et al., 2016, 2017; Prigent et al., 2018b) or beneath warm subduction zones (where similar temperatures, lithologies and mechanical coupling are expected at $\sim 60 \mathrm{~km}$ depth; Abers et al., 2017), as well as on the rheological behavior of amphibole-bearing rocks and strain localization in mid-crustal environments (e.g., continental crust: Imon et al., 2004; Tatham et al., 2008; Getsinger et al., 2013; Giuntoli et al., 2018; oceanic detachment faults or transform faults: Boschi et al., 2006; Escartín et al., 2003).

\section{Deformation of amphibolites}

Naturally and experimentally deformed amphibolites commonly show well-developed foliation and strong crystallographic-preferred orientation (CPO), regardless of their $P-T$-related water activity conditions and compositional range (e.g., Imon et al., 2004; Tatham et al., 2008; Cao et al., 2010; Getsinger et al., 2013; Ko and Jung, 2015; Marti et al., 2017, 2018; Giuntoli et al., 2018). Foliation is usually underlined by the shape-preferred orientations (SPO) of amphibole and plagioclase. Compared to plagioclase and clinopyroxene, the $\mathrm{CPO}$ of amphibole is generally stronger
(Siegesmund et al., 1994; Imon et al., 2004; Diaz Aspiroz et al., 2007; Tatham et al., 2008; Cao et al., 2010; Gómez Barreiro et al., 2010; Getsinger et al., 2013; Getsinger and Hirth, 2014; Kim et al., 2015; Ko and Jung, 2015), hence leading several authors to consider that it accounts for seismic anisotropy in the lower and middle crust (Mainprice and Nicolas, 1989; Tatham et al., 2008; Lloyd et al., 2011; Ji et al., 2013) and in subduction zones (Ko and Jung, 2015).

There are different interpretations for the strong CPO of amphibole and its SPO. The presence of a CPO usually hints at dislocation creep as the dominant deformation mechanism (e.g., Wenk and Christie, 1991). Several studies report intracrystalline deformation in amphibole at high temperature ( $T \geq 650-700^{\circ} \mathrm{C}$ ), compatible with dislocation glide along the most favorable slip systems $\{h k 0\}$ [001] (Berger and Stünitz, 1996; Diaz Aspiroz et al., 2007; Cao et al., 2010; Gomez Barreiro et al., 2010). However, other studies have suggested that amphibole is one of the strongest silicates, with a limited ability to deform by dislocation creep (e.g., Brodie and Rutter, 1985). Amphibole would rather behave as a rigid particle, rotating and fracturing (Hacker and Christie, 1990; Ildefonse et al., 1990; Nyman et al., 1992; Shelley, 1994; Berger and Stünitz, 1996; Imon et al., 2004; Ko and Jung, 2015), and/or dissolving and reprecipitating during deformation (Brodie, 1981; Hacker and Christie, 1990; Berger and Stünitz, 1996; Kruse et al., 1999; Imon et al., 2004; Marti et al., 2017, 2018; Giuntoli et al., 2018). While variations in $P-T$ conditions, water activity and grain size are known to control the activation of the different deformation mechanisms (e.g., Brodie and Rutter, 1985), their respective roles have not been clearly assessed in the specific case of amphibole.

\section{The Semail metamorphic sole}

The Semail metamorphic sole is a relatively thin unit (commonly $\leq 100 \mathrm{~m}$ thick) found at the base of the $\geq 10 \mathrm{~km}$ thick Semail ophiolite (Oman and UAE; Fig. 1a-c). This unit results from the juxtaposition of several slices of oceanic crust (Fig. 1c-d; Soret et al., 2017, and references therein) that were buried, strained and metamorphosed against the hot overlying mantle wedge, from granulite-facies (for the uppermost slice) to upper-greenschist-facies conditions (for the lowermost one). In practice, it is convenient to distinguish in the field a high-temperature (HT) sole, found directly below the mylonitic basal peridotite, from a low-temperature (LT) sole onto which the HT sole is thrust. This structural organization is found all along the Semail ophiolite (Fig. 1b-c; Gnos, 1998), from Wadi Tayin (Oman) in the south to Sumeini (Oman) and Asimah-Khubakhib (UAE) in the north. These characteristics are common to most metamorphic soles worldwide, regardless of the nature of the overlying ophiolite (see Agard et al., 2016). 

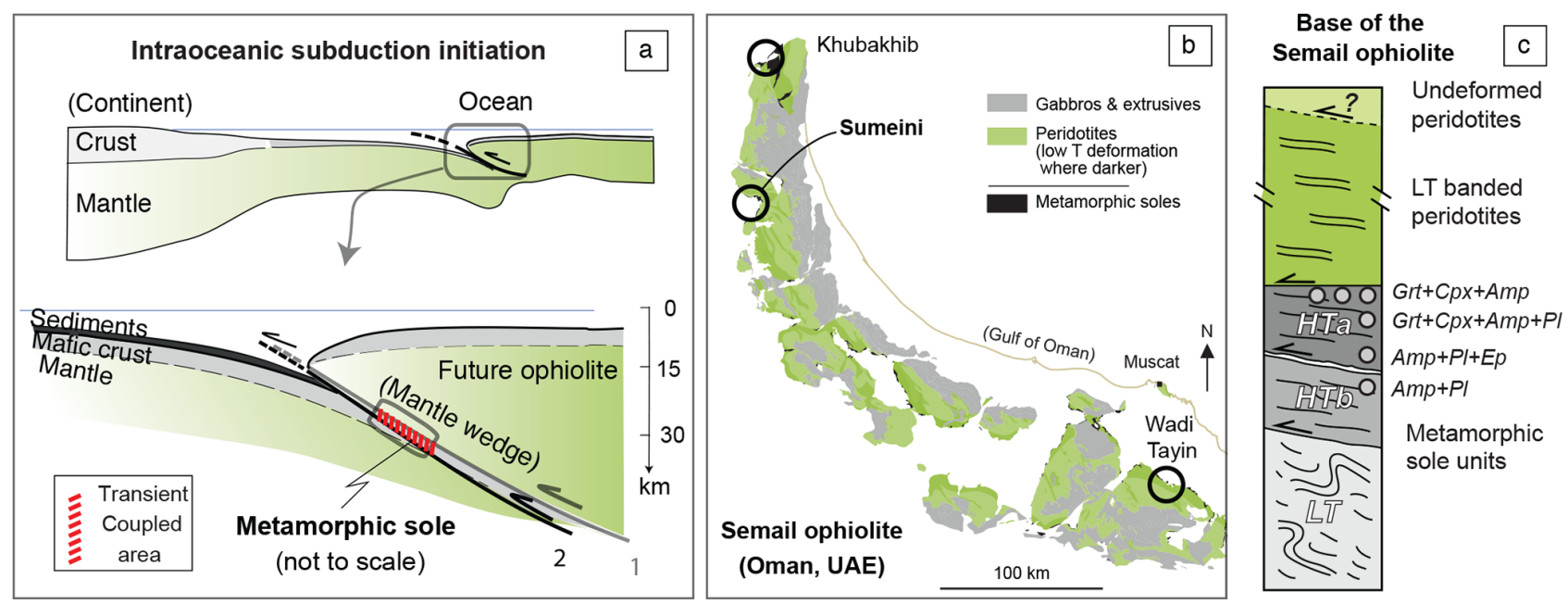

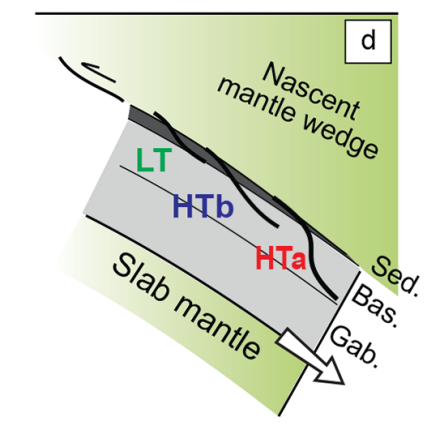

Stepwise detachment/accretion during subduction infancy
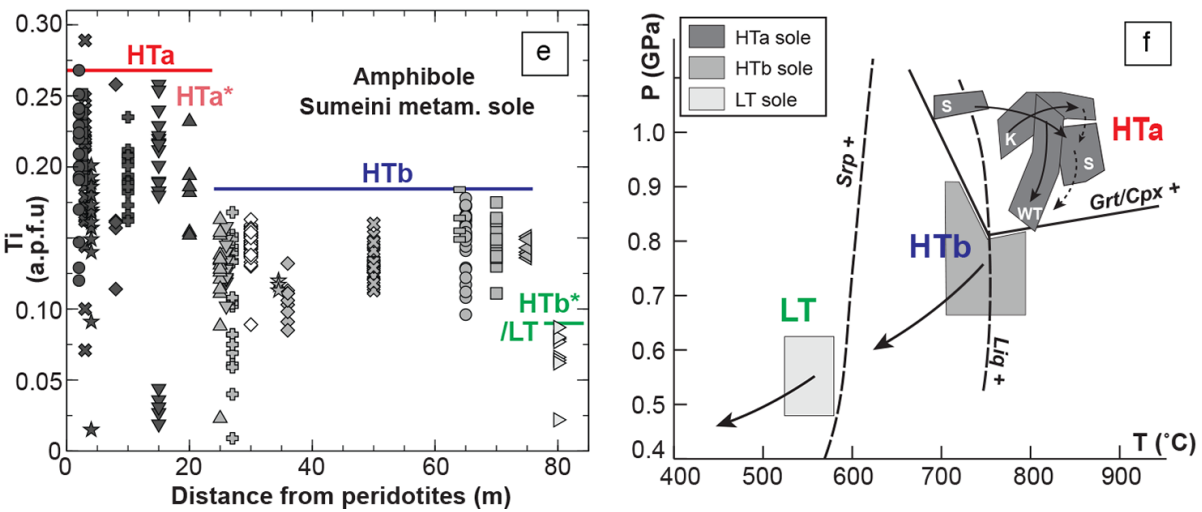

Figure 1. (a) Geodynamic setting of metamorphic sole formation during intraoceanic subduction infancy (modified after Agard et al., 2016); (b) simplified geological map of the Semail ophiolite, highlighting the outcrops of metamorphic sole beneath the ophiolite mantle (modified after Nicolas et al., 2000); (c) schematic log of the base of the Oman ophiolite showing the structural position of the samples from Khubakhib (K), Sumeini (S) and Wadi Tayin (WT). See Table 1 for details; (d) close-up view of the tectonic configuration along the nascent plate interface, during the formation and exhumation of the HTa, HTb and LT soles until reaching the steady state (sketch modified after Agard et al., 2016, and Soret et al., 2017); s: sediment, b: basalt, g: gabbro, m: mantle peridotite; (e) amphibole Ti vs. Si content in amphibolite samples from Sumeini (after Soret et al., 2017) outlining the discontinuous decrease in $T$ conditions during the exhumation of the HT metamorphic sole; (f) compilations of $P-T$ estimates and associated $P-T$ paths (after Soret et al., 2017) from the Grt-Cpx amphibolite (HTa) to the Pl-rich amphibolite (HTb) and greenschist facies (LT) metamorphic sole units.

The HT sole is composed of two major subunits (Fig. 1c), being either made of garnet-clinopyroxene amphibolites (HTa, above) or plagioclase-rich amphibolites (HTb, below). The contrasting Ti content of amphibole, which correlates positively with crystallization temperature (Ernst and Liu, 1998) and shows a stepwise decrease from $\geq 0.2$ a.p.f.u. (atoms per formula unit) in HTa to $\leq 0.15$ a.p.f.u. in $\mathrm{HTb}$ (Fig. 1e; Soret et al., 2017), indicates a $\sim 100^{\circ} \mathrm{C}$ gap in peak temperature between the two units. Mapping of the Ti content is used hereafter to track different amphibole generations (Sect. 5.3).

Peak $P-T$ conditions for the HT sole were estimated at $850 \pm 50^{\circ} \mathrm{C}$ and $0.9 \pm 0.1 \mathrm{GPa}$ for HTa and $725 \pm 50^{\circ} \mathrm{C}$ and $0.8 \pm 0.1 \mathrm{GPa}$ for HTb (Fig. 1f; see Soret et al., 2017, for details). The preservation of prograde chemical zoning (over a $\mathrm{d} T \geq 100^{\circ} \mathrm{C}$ and a $\left.\mathrm{d} P \geq 0.1 \mathrm{GPa}\right)$ suggests fast exhumation of the HT sole ( $\leq 1-2 \mathrm{Ma}$ ) after reaching peak conditions at 95-96 Ma, as supported by radiometric dating (e.g., Hacker, 1990; Rioux et al., 2016).

The underlying LT sole (Fig. 1c) is mainly composed of greenschist facies metacherts, with imbrications of amphibole-bearing metatuffs, and is not considered here. Estimated peak $P-T$ conditions are more loosely constrained at $530 \pm 50^{\circ} \mathrm{C}$ and $0.5 \pm 0.1 \mathrm{GPa}$ (Fig. 1f; Soret et al., 2017).

The entire metamorphic sole shows a strong planar fabric with evidence of both pure and simple shear deformation (Fig. $2 \mathrm{a}-\mathrm{c}$ ). In the LT sole, the lattice-preferred orientation of quartz in the interbedded quartzite is consistent with shear senses observed in the basal banded peridotite (Boudier et al., 1988; Gray et Gregory, 2000; Ambrose et al., 2018). De- 
formation is less conspicuous in the garnet-clinopyroxenebearing HTa sole compared to the HTb and LT soles in which larger lithological heterogeneities exist. HTa amphibolite is indeed homogeneous (Figs. 1c, 2a-b), fine-grained and composed of amphibole + garnet + clinopyroxene \pm plagioclase, while $\mathrm{HTb}$ amphibolite is coarser-grained and consists of amphibole + plagioclase \pm epidote with rare biotite and plagioclase-rich imbricated layers (Figs. 1c, 2c).

\section{Methods and sampling strategy}

A suite of samples was collected from the two subunits of the HT sole from three localities where the HT sole is the most complete and best preserved (Khubakhib, Sumeini and Wadi Tayin; Fig. 1b). Six samples (five from HTa and one from HTb; Fig. 1c, Table 1) were analyzed using electron back-scattered diffraction (EBSD). For clarity, only microstructures of the most complete and representative section (the three HTa unit samples from Sumeini; see Soret et al., 2017) are detailed here. Microstructural descriptions for the Khubakhib and Wadi Tayin sections are given in the Supplement.

EBSD data were collected using a CamScan X500FE CrystalProbe scanning electron microscope (SEM) at Géosciences Montpellier (France). Measurements were performed on polished thin sections at a $25 \mathrm{~mm}$ working distance with an accelerating voltage of $15 \mathrm{kV}$. For each sample (see map step size in Table 1), amphibole, plagioclase, clinopyroxene and garnet (together with prehnite, epidote and Ti-rich phases such as rutile, titanite and ilmenite) were indexed wherever present. Resulting maps were first filtered using the Channel 5 software suite (Schmidt and Olesen, 1989) to increase the quality of the maps. Isolated pixels were removed and non-indexed pixels with a minimum of six identical neighbors were filled with the same orientation. Maps were then processed using MTEX, a MATLAB toolbox for textural analysis (Hielscher and Schaeben, 2008; Bachmann et al., 2010; Mainprice et al., 2014).

In MTEX, misorientation angles (defined as the lowest rotation angle between two pixels about a common axis that brings two lattices into parallelism; e.g., Lloyd et al., 1997; Wheeler et al., 2001) were used to identify grain boundaries, applying a $10^{\circ}$ threshold between adjacent pixels. Grains with a surface smaller than 10 pixels were discarded. Twins in plagioclase were distinguished from grain boundaries by filtering out the 178 to $180^{\circ}$ misorientations during grain boundary identification. The grain size for each mineral was calculated using the equivalent circle diameter. Pole figures were calculated using the crystallographic orientation of each grain (i.e., one point per grain). All plots are represented in lower hemisphere projections in the specimen reference frame, with contours as multiples of a uniform distribution. Since thin sections were not perfectly cut parallelly to the lineation (hardly visible on the hand specimen), the latter was

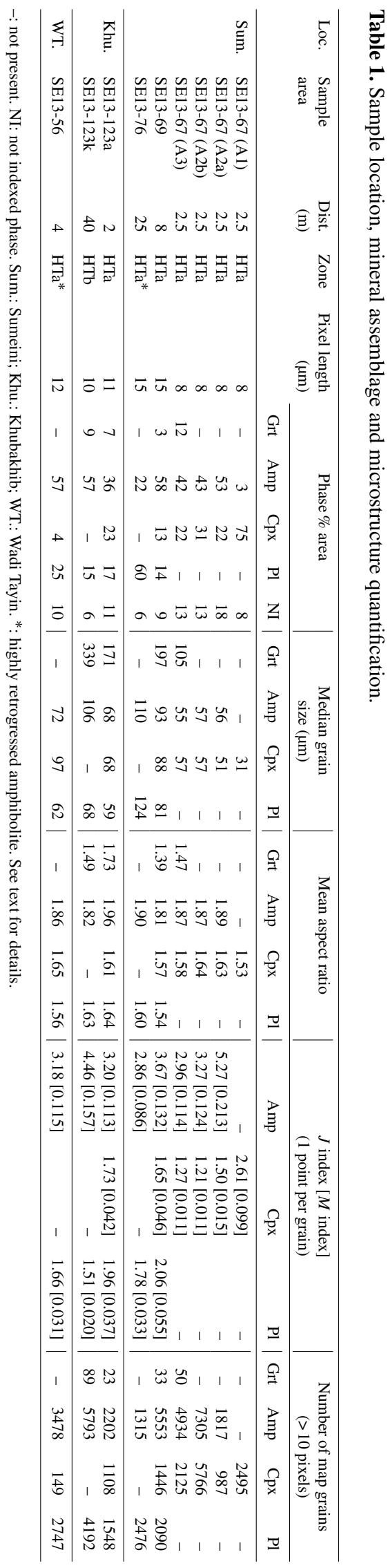

www.solid-earth.net/10/1733/2019/ 

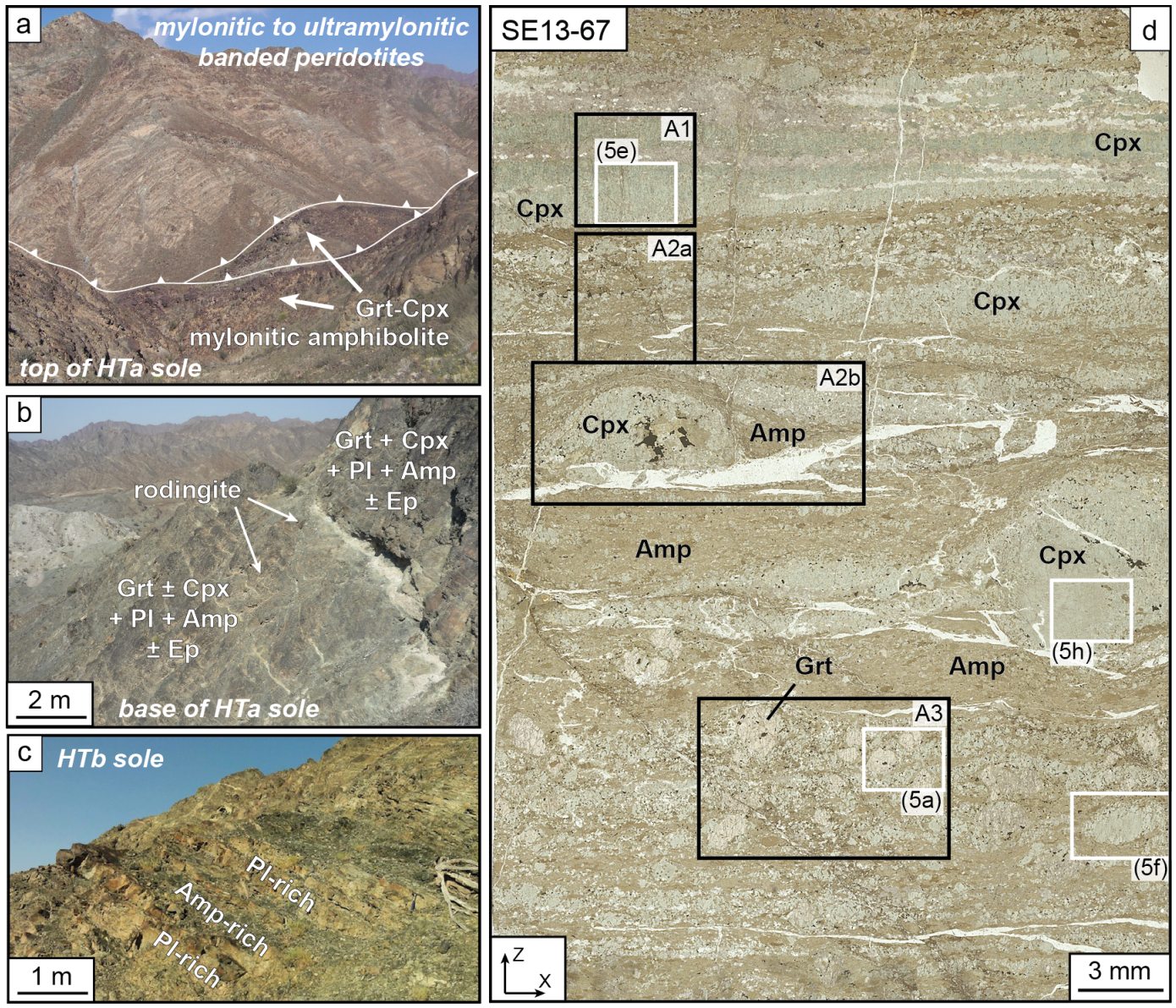

Figure 2. Photographs of the base of the Semail ophiolite outcropping in the Sumeini region (modified after Soret et al., 2017). (a) Basal contact between banded peridotite and the Grt-Cpx amphibolite of the metamorphic sole (zone HTa); (b) base of the HTa unit, widely affected by Ca-rich metasomatism (rodingitization); (c) layered structure in zone HTb with alternations from plagioclase-rich to darker amphibolerich layers; (d-h) well-preserved mineral equilibrium texture and deformation structure from peak conditions in the HTa amphibolite at Sumeini ( $\sim 2.5 \mathrm{~m}$ from the contact). Black boxes refer to EBSD maps shown in Figs. 3 and 4 . White boxes correspond to photographs in Fig. 5.

defined on the pole figures by the amphibole $c$-axis maxima (point " $X$ " in Figs. 8, 11 and 12). Mineral crystallographicpreferred orientation (CPO) strength was characterized using the $J$ index (from 1 in the case of random orientation distribution to infinity in the case of an ideal single crystal; Bunge, 1982), calculated from the orientation distribution function (ODF; Mainprice et al., 2014). The shape-preferred orientation (SPO) was calculated from the average orientation of the long axis of the best-fit ellipse of each grain. The aspect ratio (AR) of grains corresponds to the length ratio between the long and short axes of the best-fit ellipse. Kernel average misorientation (KAM) analysis was used to map intragranular misorientations in clinopyroxene, plagioclase and amphibole. The KAM is defined as the average misorientation around a measurement point with respect to the 16 nearestneighbor points in a particular grain.

To track nucleation and dissolution-precipitation processes during the deformation of amphibole and clinopyrox- ene, composition maps (Figs. 6,7) were acquired with 1$3 \mu \mathrm{m}$ spatial resolution. Major elements were measured at CAMPARIS (Sorbonne University) using a CAMECA SX5 electron microprobe. Classical analytical conditions were used $(200 \mathrm{kV}, 40 \mathrm{nA}$, wavelength-dispersive spectroscopy mode), using $\mathrm{Fe}_{2} \mathrm{O}_{3}(\mathrm{Fe}), \mathrm{MnTiO}_{3}(\mathrm{Mn}, \mathrm{Ti})$, diopside (Mg, $\mathrm{Si})$, orthoclase $(\mathrm{Al}, \mathrm{K})$, anorthite $(\mathrm{Ca})$ and albite $(\mathrm{Na})$ as standards. See Soret et al. (2017) for representative point analyses of garnet, amphibole, clinopyroxene, feldspar and epidote in these samples.

Mineral abbreviations used throughout the text and figures are given after Whitney and Evans (2010). 


\section{Results}

\subsection{Sample overview}

Samples from the Sumeini HTa unit are presented structurally from top to bottom, starting from the highest-grade samples collected near the contact with the overlying peridotite to garnet-free samples away from the contact. Mineral occurrences and proportions are given in Table 1.

Within $2.5 \mathrm{~m}$ from the peridotite, the metamorphic sole is composed of a garnet-clinopyroxene-bearing amphibolite. Peak metamorphic assemblage and microstructures are well preserved in sample SE13-67 (Fig. 2d; Soret et al., 2017). The garnet-clinopyroxene amphibolite SE13-67 exhibits a mylonitic foliation, locally transected at a relatively low angle $\left(15-25^{\circ}\right)$ by $C^{\prime}$-type shear bands indicating a dextral shear sense in the thin-section frame. The foliation comprises fine-grained aggregates of brown amphibole and clinopyroxene and locally comprises garnet and clinopyroxene porphyroclasts (Fig. 2d). Three disjunctive domains are distinguished in thin sections:

- Area 1 (A1) is dominantly composed of a clinopyroxene aggregate aligned in the foliation and is cut across at low angle by veins of epidote \pm prehnite \pm apatite (Figs. 2d, 3a).

- Area 2 (A2a, b) is composed of amphibole (50\%-65\%) and clinopyroxene (25\%-35\%) (Figs. 2d, 3b, c).

- Area 3 (A3) is composed of amphibole (42\%), clinopyroxene $(22 \%)$ and garnet (12\%) (Figs. 2d, 3d).

Plagioclase is either rare or absent in the matrix, and most crystals have not been successfully indexed due to pervasive late sericitization by a minute assemblage of albite + epidote + muscovite. Epidote $(\leq 2$ vol. $\%)$, apatite ( $\leq$ $1 \mathrm{vol} . \%)$ and prehnite $(\leq 5 \%)$, commonly found in veins subparallel to the foliation (Fig. 2d), testify to a late stage of Ca-rich fluid circulation at low-temperature conditions $\left(\leq 700^{\circ} \mathrm{C}\right)$, which is documented across the entire HT metamorphic sole (Fig. 2b; Soret et al., 2017).

The degree of high-temperature $\left(700-800^{\circ} \mathrm{C}\right)$ retrogression increases steadily towards the base of the HTa unit and is maximum at the contact with the HTb unit (Soret et al., 2017). Rocks located further away from the sole-peridotite contact therefore mostly record a lower temperature associated with post-temperature-peak deformation. About $8 \mathrm{~m}$ beneath the peridotite (sample SE13-69; Fig. 4a), the metamorphic sole exhibits a coarser-grained, more conspicuous foliation characterized by higher proportions of brown amphibole $(58 \%)$ and plagioclase (14\%), partly replacing clinopyroxene $(12 \%)$ and garnet $(3 \%)$. About $25 \mathrm{~m}$ below the contact (sample SE13-76; Fig. 4b), garnet and clinopyroxene no longer coexist in the metamorphic sole. Amphibole (23\%) has a brown-to-greenish-brown color and is closely associated with plagioclase (64\%), both with coarser grain size.
Amphibole grains are more scattered in the plagioclase-rich matrix and do not commonly form aggregates. The amphibolite also evidences precipitation of yellowish epidote (12\%) aligned along $C^{\prime}$-type shear bands together with fine-grained amphibole (Fig. 4b).

The underlying HTb unit is made of coarse-grained (typically $1 \mathrm{~mm}$ in diameter) plagioclase and greenish-brown amphibole aggregates, roughly in equal proportions, with rare $\leq 50 \mathrm{~cm}$ thick intercalations of biotite-plagioclase-rich amphibolite (Soret et al., 2017). Plagioclase-rich and darker amphibole-rich layers alternate throughout this unit (Fig. 2c).

\subsection{Microstructures}

\subsubsection{Amphibole}

The amphibole median grain size decreases towards the contact with the peridotite (Table 1; Fig. 3a-c), i.e., where peakmetamorphic textures are best preserved $(\leq 2.5 \mathrm{~m}$; SE13-67). In this sample, the median grain size for amphibole associated with clinopyroxene (A2; 56-57 $\mu \mathrm{m}$ ) is similar to that for amphibole associated with clinopyroxene and garnet (A3; $55 \mu \mathrm{m}$; Fig. 5a, b; Table 1). Most amphibole grains have a subhedral shape. Away from the peridotite, the amphibole median grain size increases with increasing retrogression from $93 \mu \mathrm{m}$ (at $8 \mathrm{~m}$; SE13-69; Fig. 5c) to $110 \mu \mathrm{m}$ (at $25 \mathrm{~m}$; SE13-76; Fig. 5d), and the shape becomes more anhedral, commonly characterized by interstitial overgrowths at triple junctions with plagioclase (Fig. 5d).

Large amphibole grains display irregular boundaries in all samples, especially where bounded by - altered - plagioclase or prehnite (Figs. 5c, d, 6a-d). They also show intragranular microfractures which are parallel to cleavage planes or perpendicular to the [001] direction (Fig. 6a-d). These microfractures locally dissect the large grains, forming smaller grains with straight and sharp intraphase boundaries (Fig. 6a-d). Later and wider prehnite-filled fractures are also found transecting the amphibolite (Fig. 5b).

The mean aspect ratio of amphibole $(1.9 \pm 0.6)$ does not vary with the distance from the peridotite nor with the mineral assemblage (Fig. S2a). Amphibole shape-preferred orientation (SPO), subparallel to the shear plane, is very strong in all samples and its intensity correlates positively with grain size and aspect ratio (Fig. S2a).

In the HTa unit, only rare $(<5 \%)$ amphibole grains show microstructural evidence of intracrystalline plasticity as undulatory or patchy extinction (Fig. 6a-b) and subgrain boundaries. However, in the sample best preserved from retrogression (SE13-67) the kernel average misorientation (KAM) maps outline the presence of intracrystalline misorientations in most amphibole grains. Most of these misorientations are associated with significant rotations (up to $6^{\circ}$; Fig. 6e-i). Grains with the high-microfracture density show the highest misorientation angles or new grain boundaries (red arrows; Fig. 6a, e). In the more retrogressed sam- 

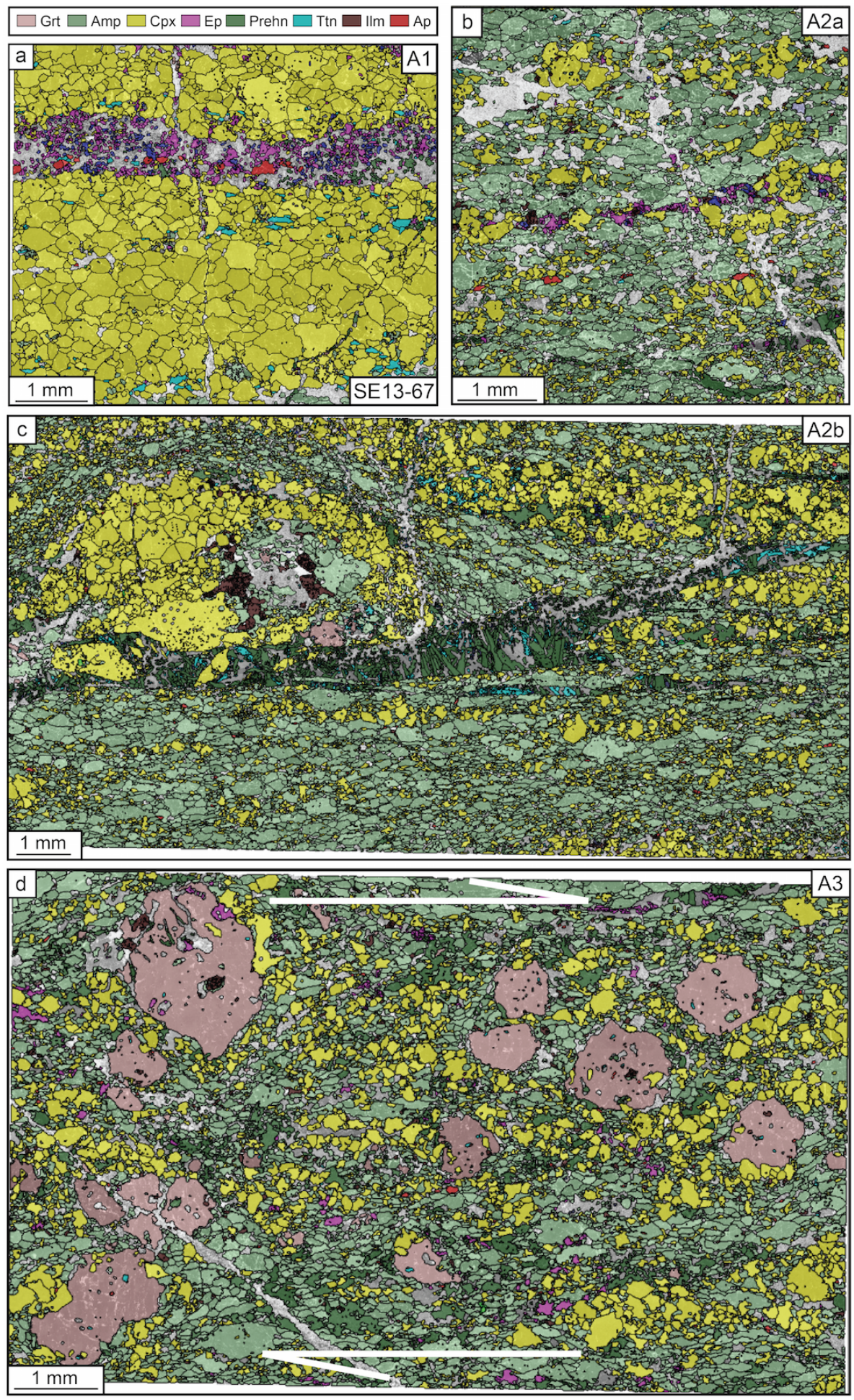

Figure 3. EBSD phase maps from a Grt-Cpx-bearing amphibolite sampled at $\sim 2.5 \mathrm{~m}$ from the contact with peridotite (sample SE13-67) and showing the best-preserved microstructures. (a) Area 1 (A1) composed essentially of clinopyroxene with a late vein of epidote; (b) and (c) Area 2 (A2) composed of amphibole and clinopyroxene. (c) A late prehnite vein crosscuts the sample; (d) Area 3 (A3) composed of garnet, amphibole and clinopyroxene. 

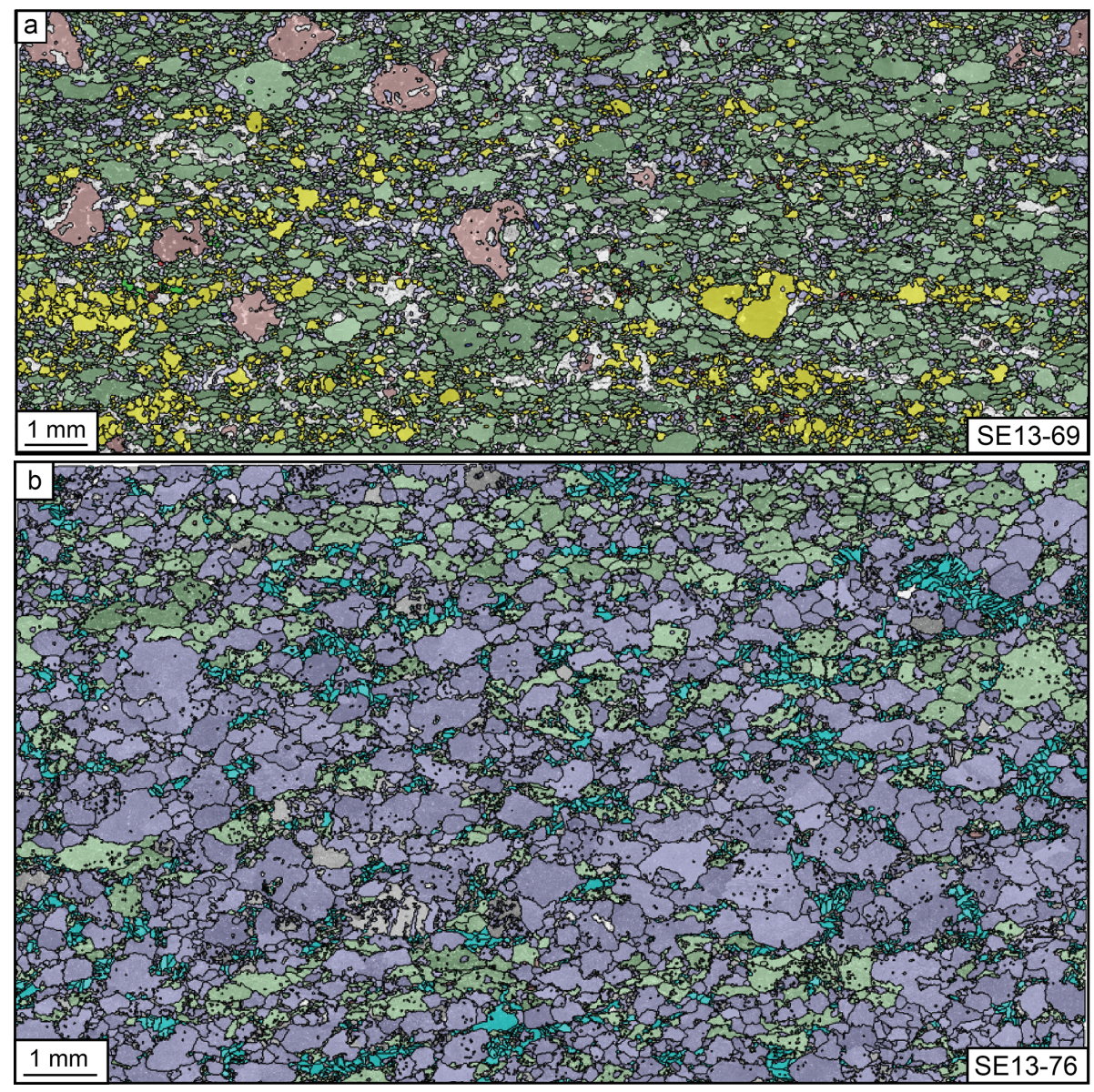

Figure 4. EBSD phase maps (a) from a slightly retrogressed, at amphibolite facies, garnet-clinopyroxene-bearing amphibolite at the top of HTa unit (sample SE13-69; Sumeini area); (b) from a highly retrogressed garnet-clinopyroxene-free amphibolite at the base of HTa unit (sample SE13-76; Sumeini area).

ples (SE13-69, SE13-76), amphibole grains also show a high density of microfractures (Fig. 6c, d), which are associated with high intragranular misorientations (Fig. 6h, i). In both samples, some of these intracrystalline misorientations are spatially correlated with undulatory extinction and subgrain formation (Fig. 6c, h), especially in the largest and/or most elongated amphibole grains (i.e., which can locally show intragranular fractures; Fig. 6d-i).

\subsubsection{Garnet}

Garnet grains have rounded-to-ellipsoidal shapes (Figs. 2d, $5 \mathrm{a}, \mathrm{b})$ and essentially form $\sigma$-type porphyroclasts showing a dextral sense of shear in the thin-section frame (Figs. 2d, 5a). Pressure shadows are composed of fine-grained amphibole and clinopyroxene. Garnet crystals are fractured and, locally, fragmented (Fig. 5b). These fractures cut across their prograde growth zonation (Soret et al., 2017) and are filled with oriented, fine-grained mixtures of amphibole + clinopyroxene \pm rare plagioclase (Fig. $5 b$ ). Where retrogression is more pervasive (SE13-69), garnet is rimmed by plagioclase (Figs. 4a, 5c) and lacks of pressure shadows.

\subsubsection{Clinopyroxene}

Clinopyroxene grains have euhedral-to-ellipsoidal shapes (Figs. 2d, 5e-h). The aspect ratio of clinopyroxene is smaller than that of amphibole $(1.6 \pm 0.4$ on average $)$ and does not vary with grain size, mineral assemblage or with the distance of the samples to the peridotite contact (Fig. S2e). Within monomineralic layers (A1 in SE13-67; Figs. 2d, 3a, 5e), clinopyroxene has a median grain size of $31 \mu \mathrm{m}$ (Fig. S2d). Where associated with amphibole (A2) and/or garnet (A3), the median grain size $(51-57 \mu \mathrm{m})$ is similar to that of amphibole (Fig. S2d). Yet, clinopyroxene forms in places $\sigma$-type porphyroclasts (A2 in SE13-67; Figs. 2d, 3b-c, 5f) with high aspect ratios $(\geq 2)$. They are usually aligned in the foliation plane (Figs. 2d, 5f, S2f), while the SPO for small clinopyroxene grains are more random (Fig. S2f).

The core of clinopyroxene porphyroclasts is characterized by undulose extinction and trails of secondary fluid inclu- 

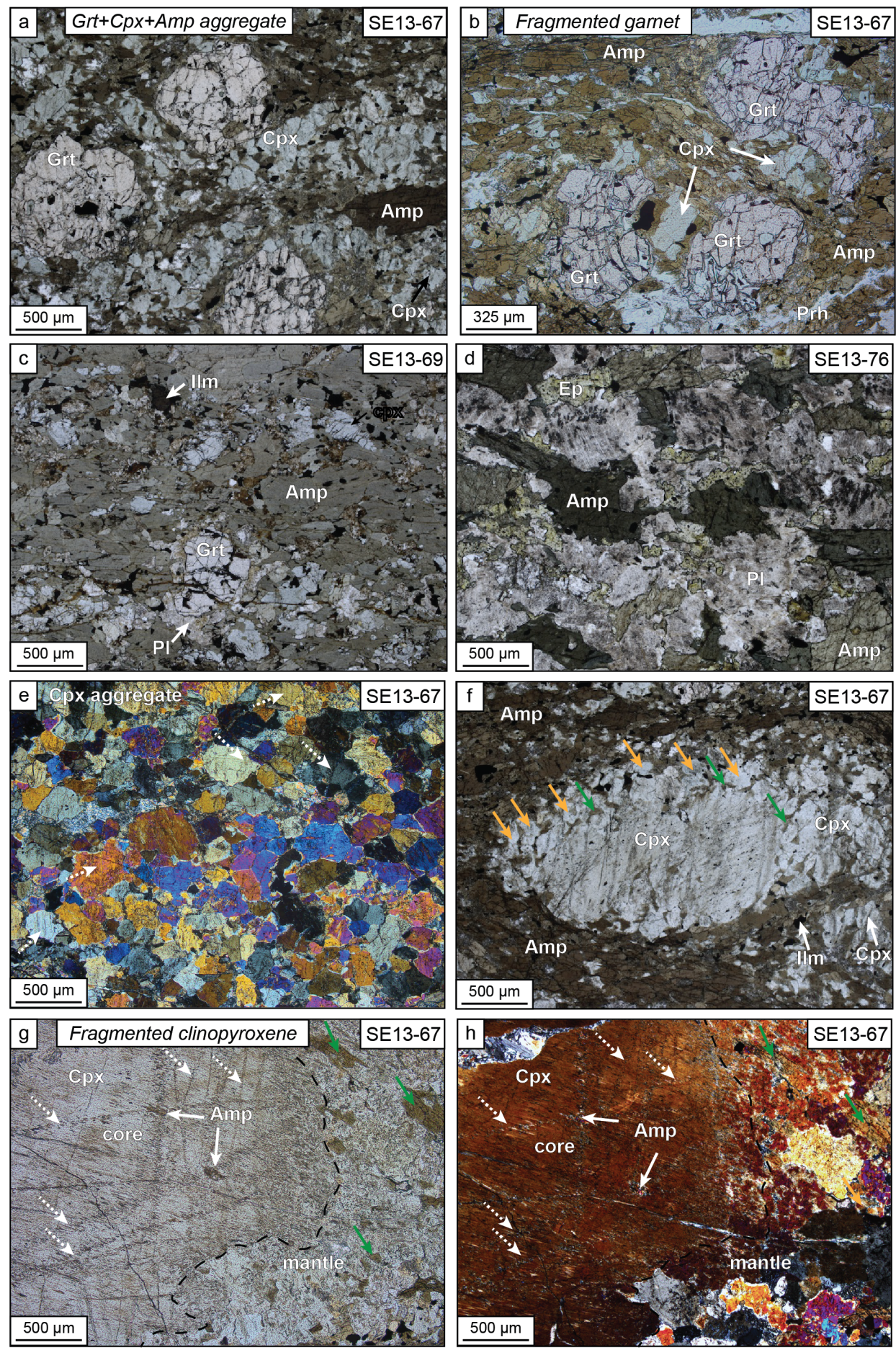

Figure 5. Photographs of representative microstructures in the HTa amphibolites. (a) Garnet porphyroclasts surrounded by a fine-grained matrix of Cpx + Amp (Area 3); (b) fractured garnet porphyroclast with fractures filled by a fine-grained matrix composed of Cpx + Amp; (c) $\sim 8 \mathrm{~m}$ from the contact, showing greater retrogression characterized by an increase in plagioclase and brown amphibole at the expense of $\mathrm{Grt}+\mathrm{Cpx} ;(\mathbf{d}) \sim 25 \mathrm{~m}$ from the contact (base of HTa), highly retrogressed amphibolite associated with secondary crystallization of coarsegrained brown-to-green amphibole, epidote and plagioclase; (e) monomineralic layer of recrystallized clinopyroxene by subgrain rotation; (f) sheared Cpx porphyroclast wrapped by fine-grained brown Amp (Area 2); (g) and (h; cross polarized light) core-and-mantle structure in a Cpx porphyroclast with and minute amphibole in sealed microfractures (fluid inclusions trails) and at grain boundaries of the porphyroclast mantle. Orange and green arrows point to small new clinopyroxene deriving from the fragmented clinopyroxene porphyroclast and secondary amphibole, respectively. See details in the text. 

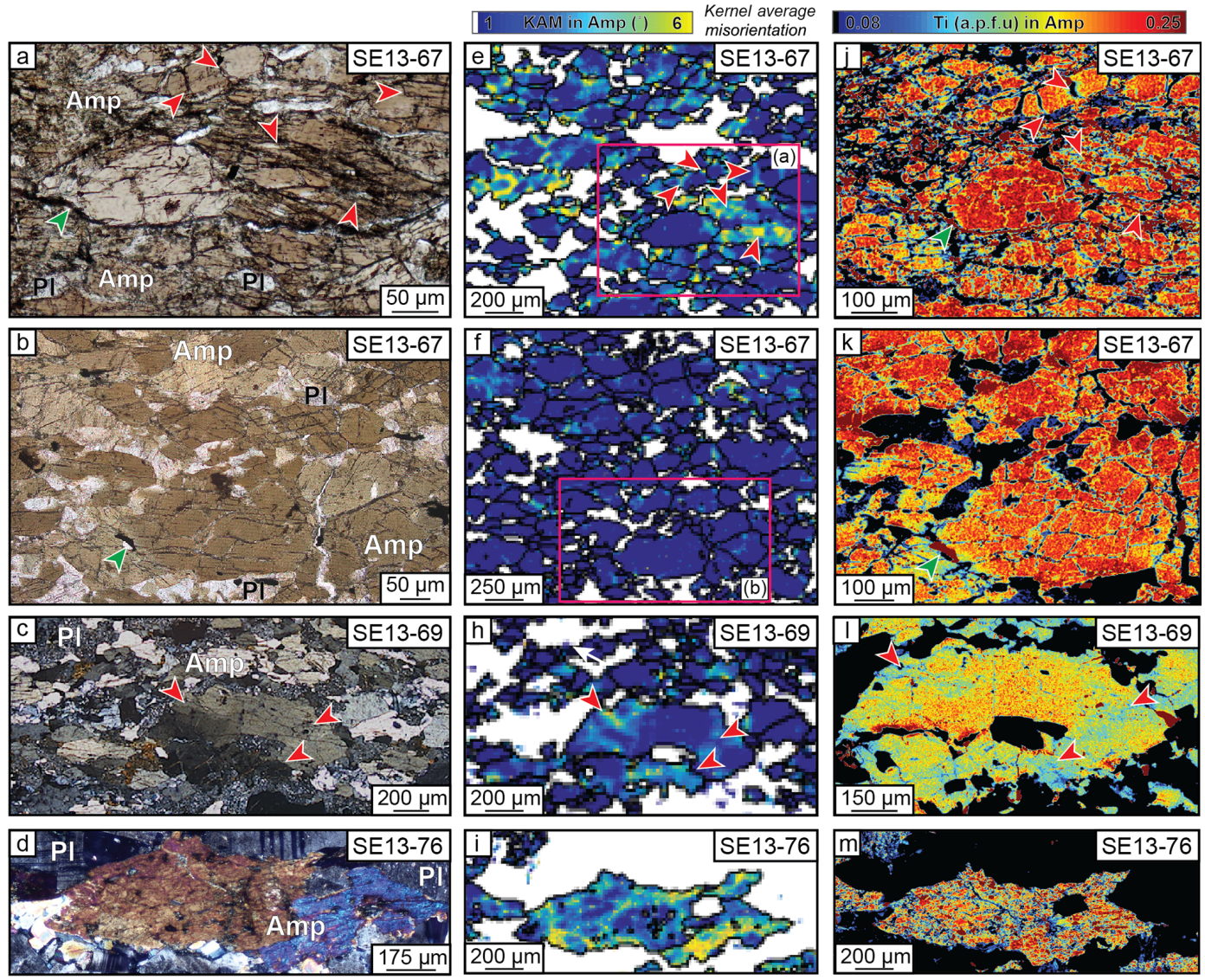

Figure 6. (a-d) Photographs of representative textures of amphibole, $(\mathbf{e}, \mathbf{f}, \mathbf{h}, \mathbf{i})\left(2-10^{\circ}\right)$ intracrystalline misorientation (to the mean grain orientation) and ( $\mathbf{j}-\mathbf{m})$ compositional map of $\mathrm{Ti}$ of amphibole in samples sorted as a function of the distance from the peridotite. Red and green arrows point to amphibole microfractures and ilmenite veinlets or crystals, respectively.
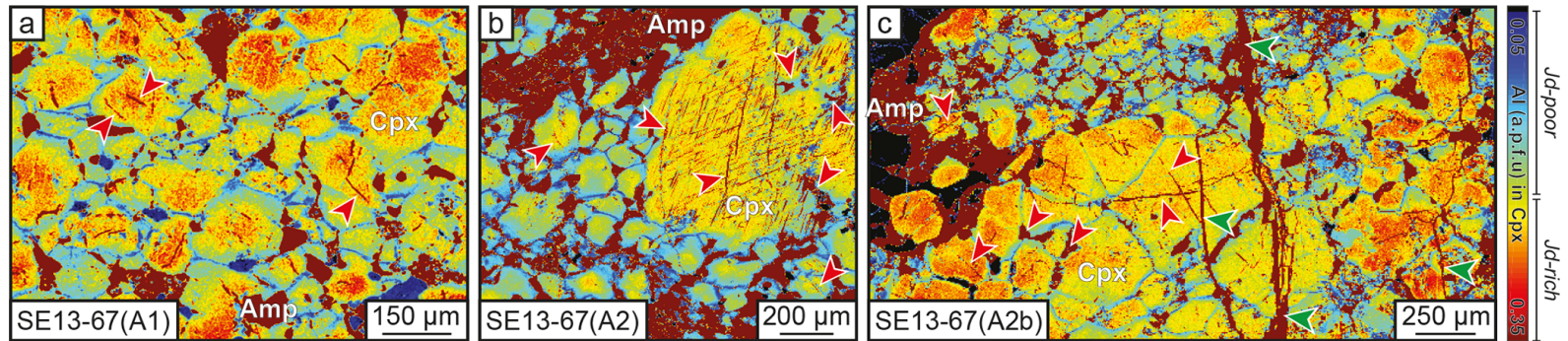

Figure 7. (a) Compositional map of $\mathrm{Al}$ of clinopyroxene in mono- and polymineralic layers of sample SE13-67. Red arrows point to amphibole in clinopyroxene microfractures or in interstitial positions at new clinopyroxene boundaries; Jd: jadeite content; see the text for details.

sions representing healed fluid-filled microfractures (dashed white arrows; Fig. 5g, h). Minute amphibole is found along the cleavages and the microfractures (white arrows; Fig. 5h). These trails are locally cut across by the wider prehnite-filled fractures.

Clinopyroxene mantle also shows elongated fine-grained wings (consistent with dextral sense of shear in the thinsection frame; Fig. 2d) composed of small grains of variable size but with a median value similar to that of the new grains scattered in the matrix and in monomineralic layers (A1). Some of these small grains display undulose extinction (Fig. 5h). However, they rarely contain microfractures. Interstitial small amphibole grains (green arrows; Fig. $5 \mathrm{~g}-\mathrm{h}$ ), randomly oriented, are typically found in the porphyroclast mantle and wings at the triple junction of the new clinopyroxene grains (Fig. $5 \mathrm{~g}-\mathrm{h}$ ).

Where garnet is present (A3 in SE13-67, SE13-69; Figs. 2d, 5a), clinopyroxene grains form fine-grained ag- 
gregates embedded in an amphibole-rich matrix. In sample SE13-67, most amphibole grains have a subhedral shape (Fig. 5a). However, the degree of phase mixing with amphibole in the matrix is higher than in Area 2, especially in sample SE13-69, characterized by precipitation of secondary amphibole at the expense of clinopyroxene.

\subsubsection{Plagioclase}

Plagioclase is rare, even in the best-preserved metamorphic sole samples. The analysis of the crystallographic orientation in plagioclase grains is complicated by retrogression; therefore, the results shown below are restricted to the bestpreserved grains and may not be representative of all grains formed at high $P$ and $T$.

\subsection{Mineral composition mapping}

\subsubsection{Amphibole}

Amphibole composition plots within the pargasite to actinolite fields (see Soret et al., 2017, for detailed analyses). Hereafter, amphibole is referred to as Ti-high ( $\geq 0.2$ a.p.f.u.), Timedium (0.1-0.2 a.p.f.u.) and Ti-low ( $\leq 0.1$ a.p.f.u.) amphibole.

In sample SE13-67, amphibole grains show an homogeneous Ti-high composition (Fig. 6j-k), confirming that these grains formed at or near peak conditions. Interstitial amphibole grains have a Ti-medium composition, indicating a nucleation during the onset of cooling. The opaque mineral and veins found along amphibole grain boundaries and microfractures correspond to ilmenite (green arrow; Fig. 6a, b, j, k) which also formed at slightly lower $P-T$ conditions (Soret et al., 2017).

In the samples marked by a higher degree of retrogression at amphibolite-facies conditions (SE13-69, SE13-76), amphibole grains evidence a much more complex and patchy zoning pattern including smaller Ti-rich areas than in sample SE13-67. These Ti-rich areas are usually truncated by Ti-medium to Ti-low areas, especially along microfractures (red arrows; Fig. 61-m). In addition to the precipitation of secondary plagioclase and ilmenite at amphibole lobate grain boundaries and/or along the microfractures (Fig. 6a-c), these zoning patterns indicate dissolution-precipitation during cooling (i.e., $800-700^{\circ} \mathrm{C}$ ). This also further supports the observation that Ti-medium and Ti-low amphibole grains are not in equilibrium with clinopyroxene and garnet but rather with plagioclase.

\subsubsection{Clinopyroxene}

Clinopyroxene has a diopside-rich composition with small variations in jadeite content $(\mathrm{Na}, \mathrm{Al})$. Hereafter, clinopyroxene is distinguished as jadeite-rich ( $\mathrm{Al}>0.2$ a.p.f.u.) and jadeite-poor $(\mathrm{Al}<0.2$ a.p.f.u. $)$ clinopyroxene, recording the peak-pressure condition and the early exhumation conditions, respectively (Soret et al., 2017).

Clinopyroxene porphyroclasts have a jadeite-rich core similar in composition to that of inclusions in garnet and a thin jadeite-poor rim (Fig. 6a-c). The jadeite-rich core is truncated by microfractures which are both filled by Tirich to Ti-medium amphibole (red arrows; Fig. 6a-c). At the edges of the largest microfractures dissecting the porphyroclast core, compositions are jadeite poor.

Small clinopyroxene grains in mono- and polymineralic layers display a zoning pattern similar to that of the clinopyroxene porphyroclasts, with jadeite-rich cores rimmed and locally truncated by jadeite-poor domains (Fig. 6a-c). As for clinopyroxene porphyroclasts, some of the small grains exhibit amphibole-bearing microfractures in the jadeite-rich core only.

\subsection{Crystallographic-preferred orientation}

\subsubsection{Amphibole}

In all samples (SE13-67, SE13-69 and SE13-76), amphibole has a very strong CPO, with [001] axes (i.e., shortest Burgers vector; Hacker and Christie, 1990) mostly parallel to the lineation (Figs. 8a, 9a-c). Poles to (100) are subperpendicular to the foliation and poles to (010) are in the foliation, subperpendicular to the lineation (Fig. 8a). Poles to (100) always show the highest density and poles to (010) usually display the weakest preferred orientation.

Amphibole $J$ index ranges from 2.86 in the sample SE1376 to 5.27 in the sample SE13-67 (Fig. 10a-b). The CPO strength is slightly positively correlated with the modal proportion of amphibole but no systematic correlation is found with the distance to the peridotite (Fig. 10a-b). In sample SE13-67, the CPO strength is significantly weakened around garnet and clinopyroxene porphyroclasts which show strong foliation deflection. In the more retrogressed sample SE1369 , where garnet and clinopyroxene coexist but do not deflect the foliation plane, amphibole has a strong CPO fabric ( $J$ index $=3.67$; Fig. 10a-b) as in the garnet-free layers of SE1367 (Area 2a). The weakest CPO $(J$ index $=2.87$; Fig. 10a-b) is observed away from the contact in the garnet-free sample SE13-76, which has the smallest amphibole modal proportion. Moreover, as highlighted with the SPO, amphibole grains with smaller grain size $(<80 \mu \mathrm{m})$ and/or aspect ratio $(<1.5)$ display a similar CPO pattern but significantly weaker in intensity compared to larger or more elongate grains (Fig. 10c).

The misorientation angle distribution of amphibole in all samples highly differs from the theoretical random distribution (i.e., the "Uniform" green curve; Fig. 8b). This is consistent with the strong intensity of amphibole CPO. Small misorientation angles (from 2 to $10^{\circ}$ ) are largely dominant. They correspond to rotations around the [001] axis and to a much lesser extent around the [010] axis (Fig. 8c). The [010] axis 

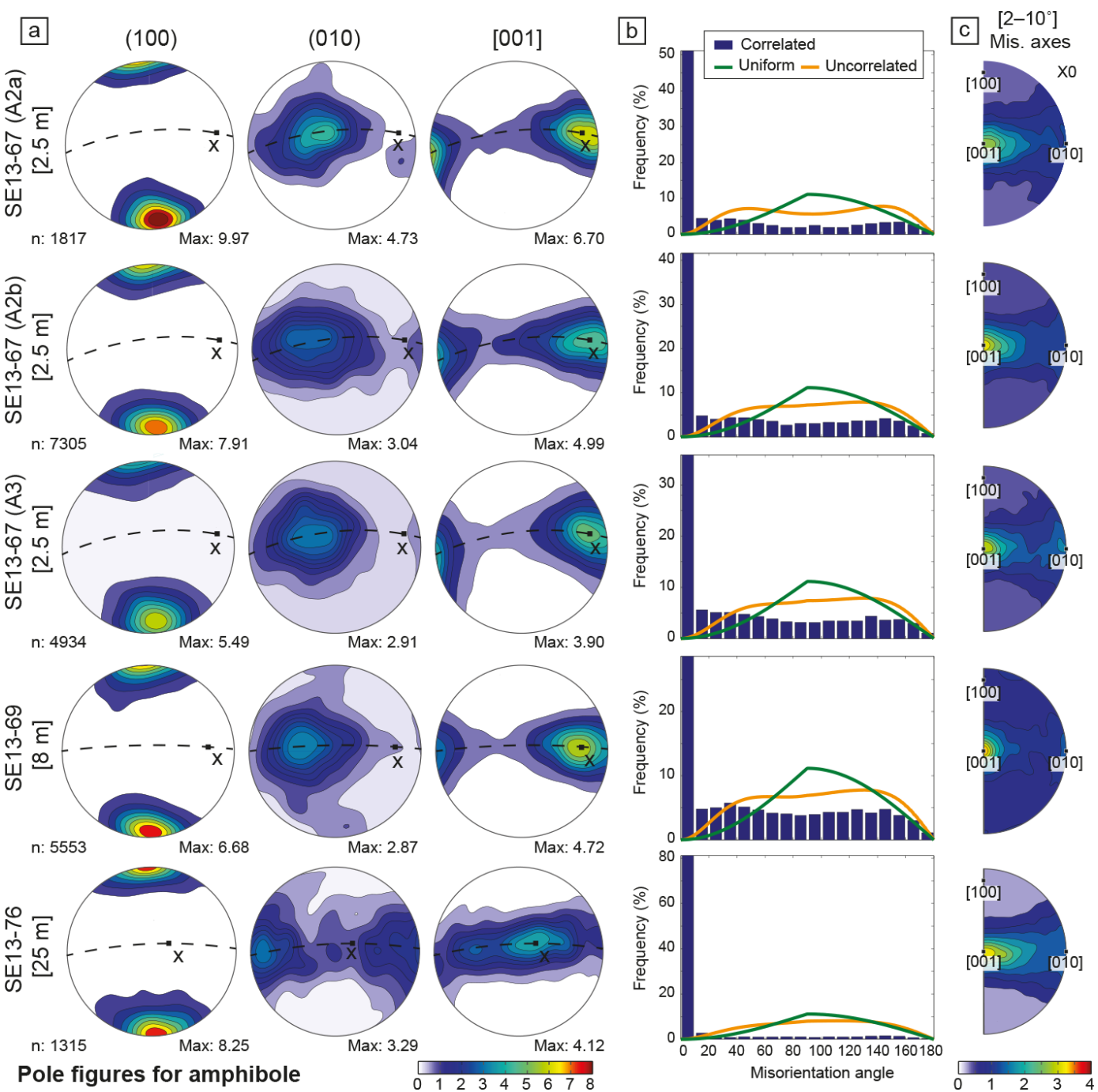

Figure 8. (a) Pole figures illustrating amphibole CPO of the samples from the HTa unit in Sumeini massif. Samples are sorted using the distance from the peridotite, with increasing distance downwards. The dashed line represents the foliation and $\mathrm{X}$ points to the lineation. Contours are multiples of a uniform distribution. All plots are lower hemisphere projections. Numbers in square brackets refer to the distance to the peridotite. $n$ : number of grains; (b) distribution of misorientation angles between correlated (adjacent) pixels (blue histogram) and between uncorrelated pixels (orange curve) of amphibole. The uniform (green) curve corresponds to the theoretical misorientation distribution for perfectly randomly oriented crystals; (c) amphibole inverse pole figures showing the distribution of correlated misorientation axes (between 2 and $10^{\circ}$ ). Contours are multiples of uniform distribution.

concentration is slightly higher in sample SE13-76 compared to the other samples.

\subsubsection{Clinopyroxene}

Clinopyroxene has a moderate to weak CPO. As in amphibole, the [001] maximum is subparallel to the lineation but more dispersed (Figs. 9d-f, 11a, S5b). The majority of CPO patterns has girdle concentrations of both (100) and (010) poles, except in sample SE13-69 where poles to (010) have a maximum normal to the foliation (Fig. 11a). In SE13-67, the strongest CPO (or $J$ index) is found within monomineralic layers of SE13-67 ( $J$ index $=2.61$ in A1; Fig. 10a).
In polymineralic aggregates, clinopyroxene $J$ index ranges from 1.21 to 1.73 (Fig. 10b). In contrast with amphibole, both the SPO and CPO strengths of clinopyroxene appear to be also largely insensitive to grain size and aspect ratio (Fig. 10c).

The misorientation angle distribution of clinopyroxene in all samples does not significantly differ from the theoretical random distribution (i.e., the "Uniform" green curve; Fig. 11b), except in the monomineralic layer A1 in sample SE13-67. Small misorientation angles (from 2 to $10^{\circ}$ ) largely prevail. They correspond to rotations essentially around the [010] and the [001] axes (Fig. 11c), which corresponds to the 

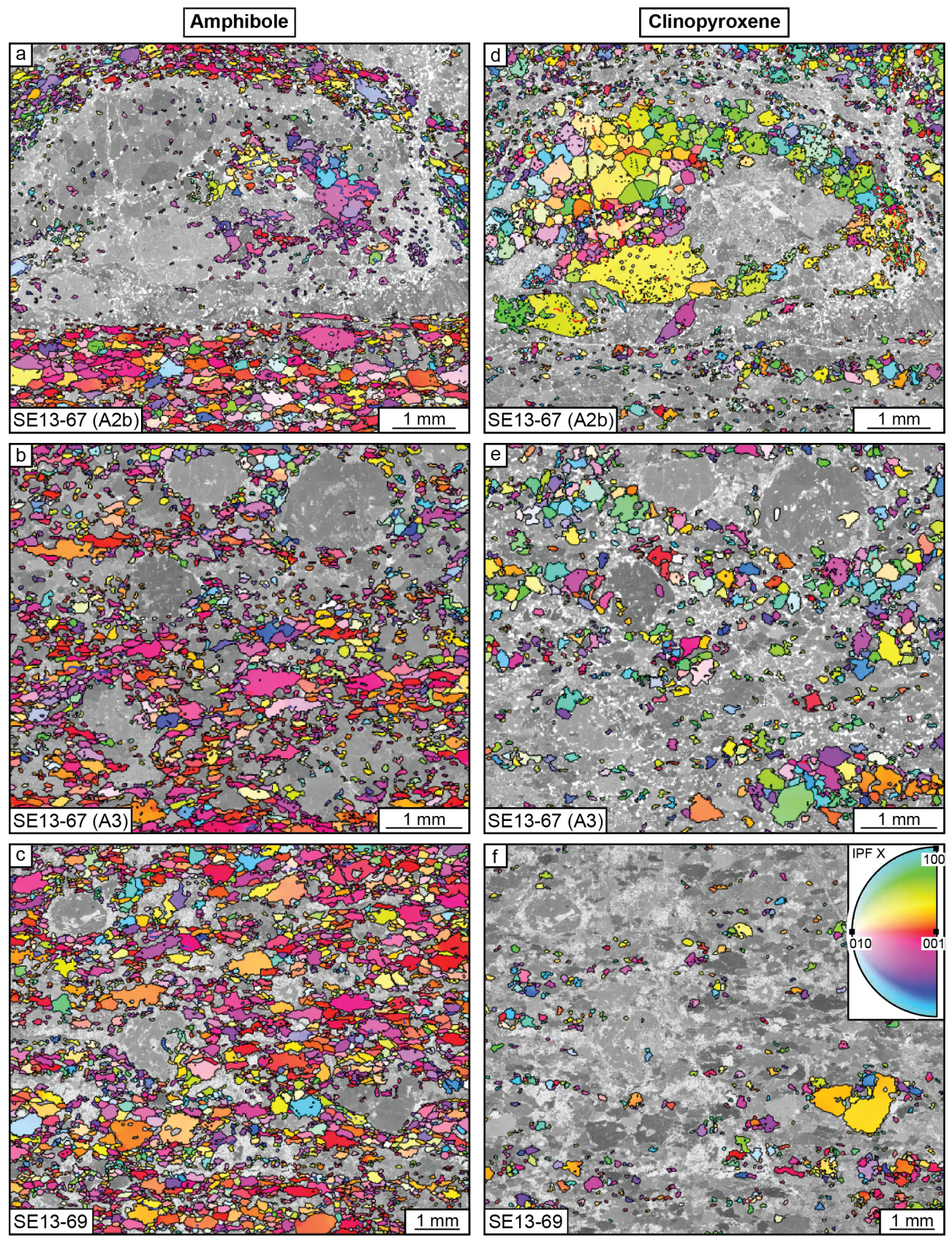

Figure 9. $X$ direction inverse pole figure (IPF) coloring orientation maps for (a-c) amphibole and (d-f) clinopyroxene.

mechanical twinning axis, as previously reported for clinopyroxene deformed at high-temperature conditions (Frets et al., 2012).

\subsubsection{Plagioclase}

Plagioclase has a weak CPO (Figs. 12a, S5c-d). Its strength is similar to that of clinopyroxene with a $J$ index varying between 1.51 and 2.06 (Fig. 10a). Plagioclase grains display a concentration of (001) poles normal to the foliation plane and [100] axes subparallel to the lineation (Fig. 12a). Poles to (010) show no preferred alignment. The CPO strength and patterns do not vary with the distance from the contact nor with the mineral assemblage.

The misorientation angle distribution of plagioclase in all samples slightly differs from the theoretical random distribution (i.e., the "Uniform" green curve; Fig. 12b). Small misorientation angles (from 2 to $10^{\circ}$ ) are largely dominant. They correspond to rotations around the twinning axis [100] and to a much lesser extent around the [001] axis (Fig. 12c). However, the [001] axis becomes the main axis of intracrys- 

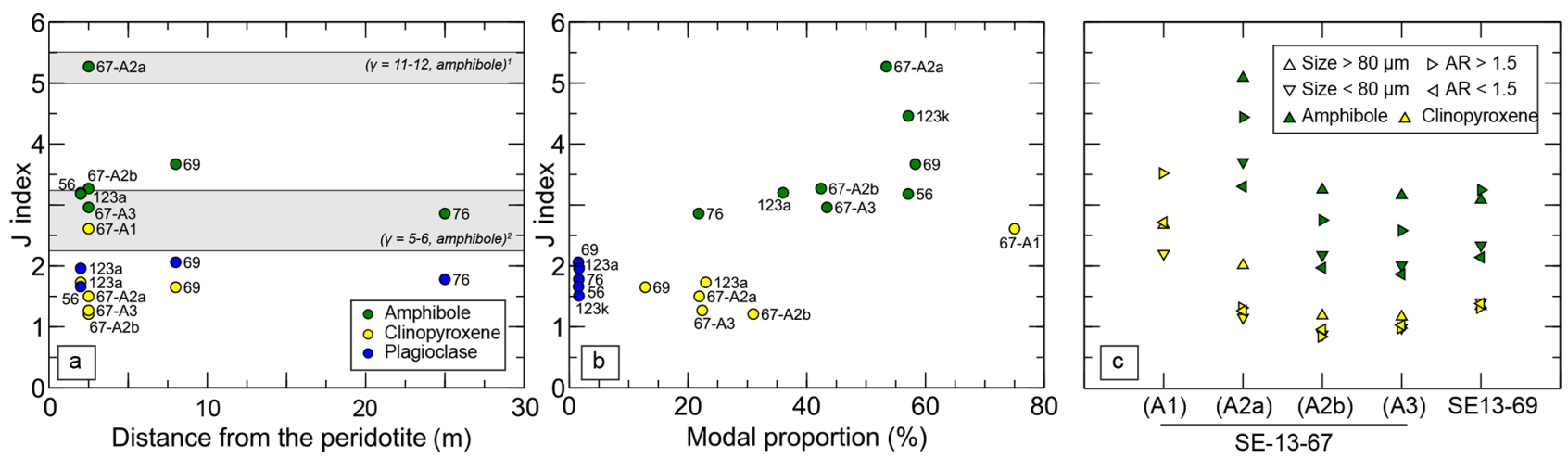

Figure 10. Quantified CPO strength (using the $J$ index) of amphibole, clinopyroxene and plagioclase vs. (a) the distance from the contact with the peridotite and (b) the modal proportion of each phases from Sumeini, Khubakhib and Wadi Tayin localities (see Table 1); (c) the $J$ index of amphibole and clinopyroxene as a function of their aspect ratio and grain size for the samples from the Sumeini cross section.

talline misorientations in sample (SE13-76), where plagioclase forms monomineralic aggregates (Fig. 12a).

\section{Discussion}

The HTa metamorphic sole unit is characterized by an intense gradient of syn-kinematic retrogression increasing toward its base. This gradient allows us to constrain the combined deformation mechanisms in amphibolites at peak conditions ( $\sim$ $850^{\circ} \mathrm{C}$ and $1 \mathrm{GPa}$; in sample SE13-67) and during cooler and more hydrated conditions $\left(\sim 800\right.$ and $\sim 750^{\circ} \mathrm{C}$ and $0.7 \mathrm{GPa}$, in samples SE13-69 and SE13-76, respectively).

Amphibolites recording peak conditions (e.g., SE13-67) show large contrasts in mineral strength and crystallographic fabric. Clinopyroxene forms $\sigma$-type porphyroclasts and monomineralic fine-grained aggregates wrapped around by monomineralic aggregates of amphibole or polymineralic aggregates of amphibole + clinopyroxene \pm plagioclase (Fig. 2d). Where garnet is present, clinopyroxene forms finegrained aggregates partially mixed within an amphibole-rich matrix. Clinopyroxene appears therefore to be mechanically stronger than amphibole and the polymineralic matrix but weaker than garnet. Yet, such a strength contrast disappears in the more retrogressed garnet-clinopyroxene amphibolite (SE13-69) where mineral reactions are more pervasive.

Moreover, clinopyroxene aggregates show ubiquitous plastic deformation (as indicated by the presence of undulose extinction; Fig. $5 \mathrm{~g}-\mathrm{h}$ ) but display a weak CPO. By contrast, amphibole aggregates in the amphibolites of the HT metamorphic sole have a very strong CPO $(J$ index $\sim 5$; Fig. 10) despite showing no or only little evidence of intracrystalline plastic deformation. Extensive phase mixing is observed throughout the rock, especially in more retrogressed samples. Finally, amphibole, clinopyroxene and garnet underwent intense grain size reduction by microfracturing, closely associated with fluid-driven mineral reactions.
In the light of our observations (see also Table 2) we discuss below the possible deformation mechanisms and their relative contributions to the mechanical behavior of the amphibolites of the soles.

\subsection{Deformation processes in amphibolite}

\subsubsection{Dislocation creep}

Amphibole SPO and CPO are similar in orientation to what is commonly reported for strained amphibole (Berger and Stünitz, 1996; Cao et al., 2010; Díaz Aspiroz et al., 2007; Elyaszadeh et al., 2018; Getsinger et al., 2013; Gomez Barreiro et al., 2010; Hacker and Christie, 1990; Imon et al., 2004; Tatham et al., 2008). They are also consistent with the extreme tectonic thinning and large shear strain of the HT metamorphic soles $(\gamma \geq 5$; Soret et al., 2017). For amphibole with $J$ index of $\sim 3$ and $\sim 5$, shear strains of $\geq 5$ and $\geq 10$ have been reported in amphibolite in deformation experiments (Getsinger, 2015) and in continental shear zones (Tatham et al., 2008), respectively (Fig. 10a). As for amphibole in the Semail HT metamorphic sole, those amphibole crystals show no or little evidence of intracrystalline plastic deformation, and coexisting phases (plagioclase, clinopyroxene and quartz) have a weak CPO.

If the strong amphibole $\mathrm{CPO}$ and the apparent intracrystalline misorientations (Fig. 8) result from plastic deformation, the misorientation axis should be perpendicular to the direction of crystal slip (e.g., Lloyd et al., 1997). In our study, however, intracrystalline misorientations are essentially accommodated around the [001] axis and only to a lesser extent around the [010] axis (Fig. 8b). Most of the misorientations are therefore incompatible with the activation of the amphibole easy slip system (100)[001] that would account for the observed CPO geometries and intracrystalline misorientations (Fig. 8a). Conversely, the [010] rotation axis (Fig. 8b), lying in the foliation plane perpendicularly to the general shear sense, is compatible with the activation of the 

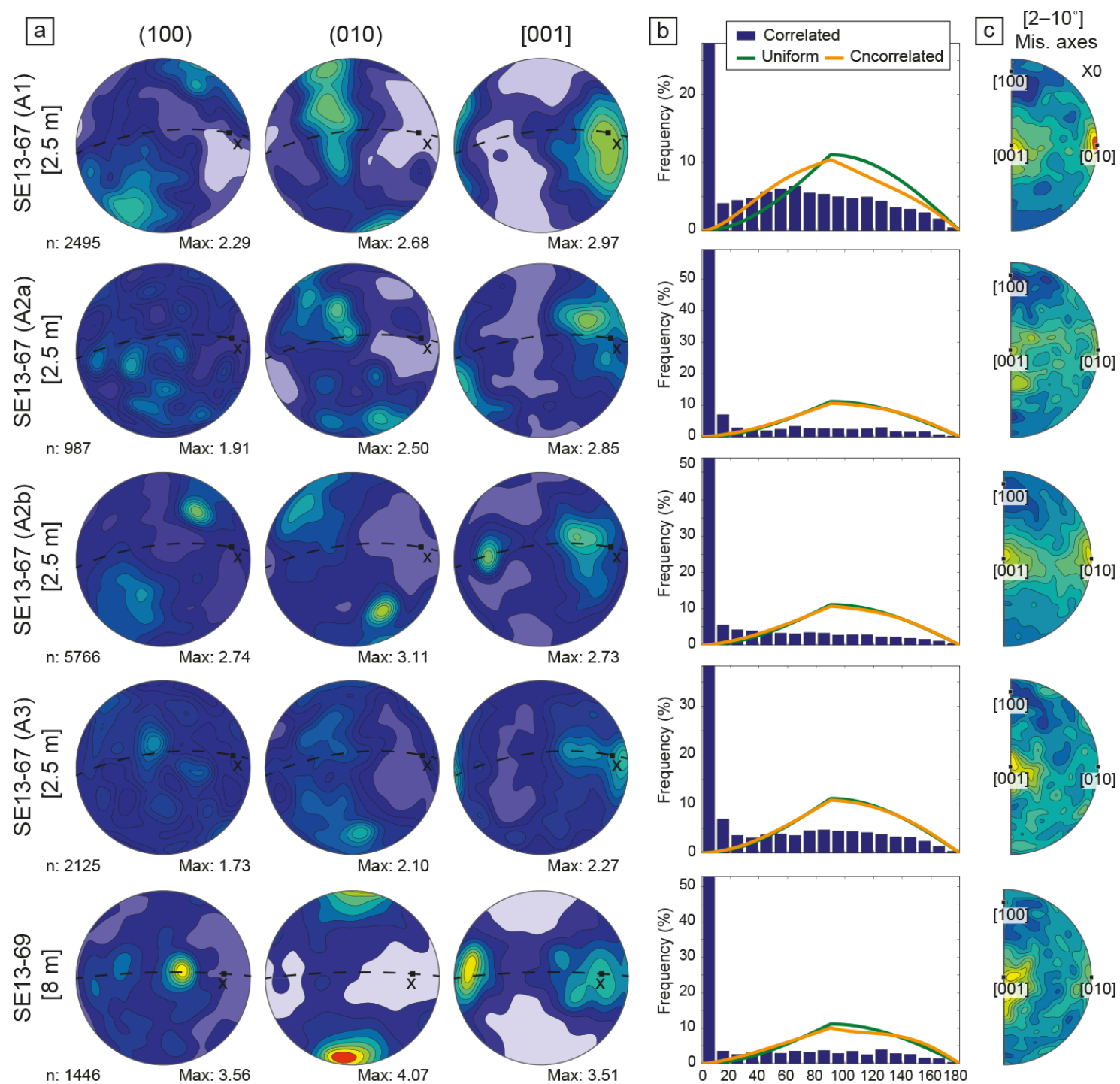

Pole figures for clinopyroxene
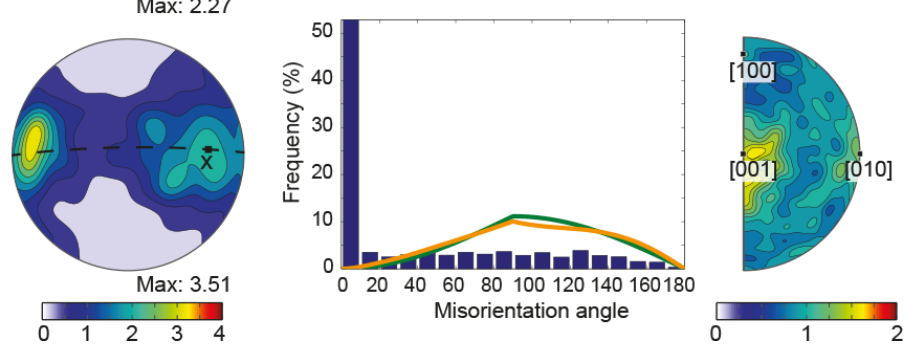

Figure 11. (a) Pole figures illustrating CPO of clinopyroxene in samples from the HTa unit of Sumeini; (b) distribution of misorientation angles; (c) inverse pole figures showing the distribution of correlated misorientation axes (between 2 and $10^{\circ}$ ). See caption of Fig. 7 for details.

amphibole easy slip system. The relatively small number of rotation axes oriented parallel to [010] is also consistent with the fact that only few of the Ti-rich amphibole grains recording peak $T$ conditions $\left(\sim 850^{\circ} \mathrm{C}\right)$ show microstructural evidence of plastic deformation (such as subgrain formation; SE13-67; Fig. 9a-c).

Clinopyroxene has a CPO pattern characterized by the [001] axis maximum subparallel to the lineation (Figs. 9df, 11a), and girdle concentrations of both (100) and (010) poles perpendicular to the lineation (Figs. 11a). This pattern reflects the dominant activation of the $\{h k 0\}$ [001] glide systems in the dislocation creep regime, as commonly reported in experiments on omphacite and diopside (Bascou et al., 2002; Getsinger and Hirth, 2014; Ingrin et al., 1991). This is consistent with the intracrystalline misorientations accommodated around the [010] axis (Fig. 11c), especially dominant in the fine-grained monomineralic aggregates. However, the CPO strength is low to moderate with some dispersion of the [001] axis even in the fine-grained monomineralic aggregates (Figs. 11a, S5b).

\subsubsection{Brittle deformation}

The high-microfracture densities in coarse amphibole grains (Figs. 5a, 6a-b) and the general fine-grained size in the bestpreserved sample (SE13-67) attest to grain size reduction through extensive brittle deformation starting at or after peak conditions. Healed microfracturing in secondary amphibole 

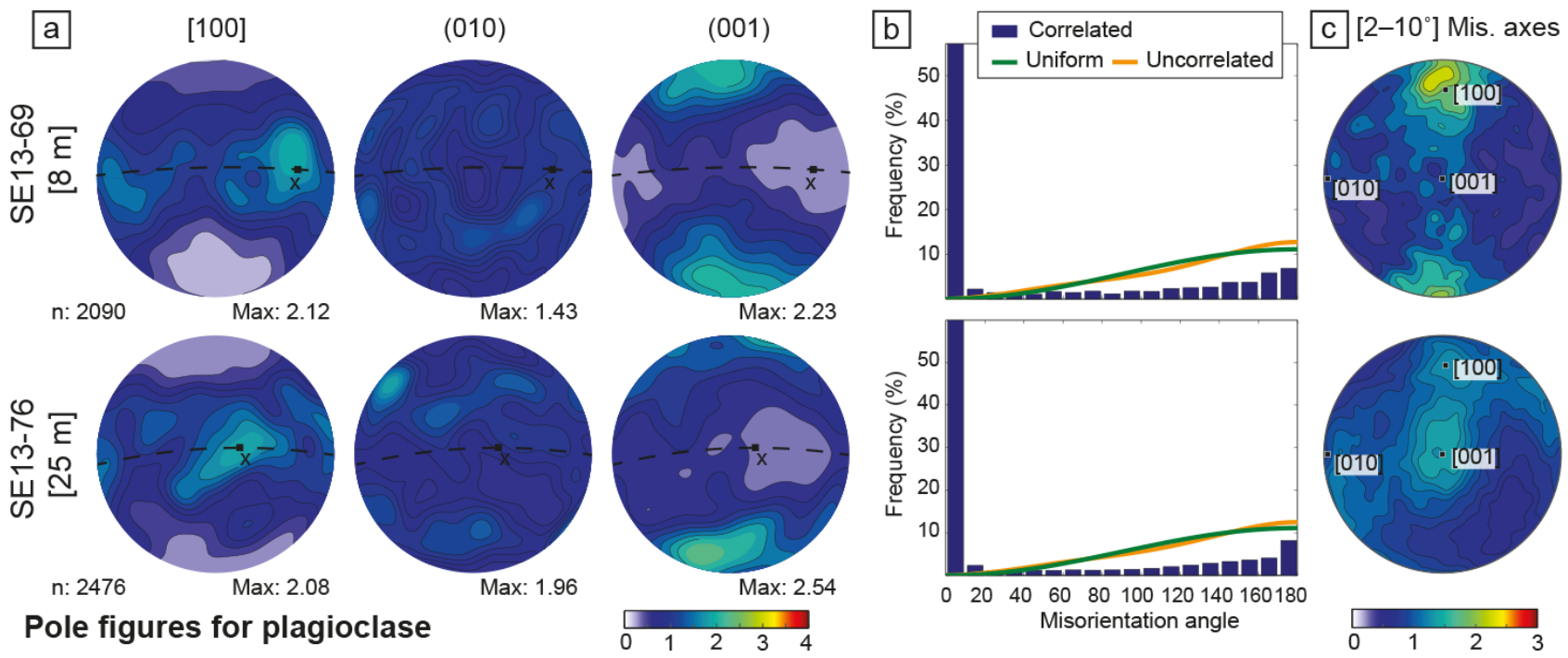

Figure 12. (a) Pole figures illustrating CPO of plagioclase in samples from the HTa unit of Sumeini; (b) distribution of misorientation angles; (c) inverse pole figures showing the distribution of correlated misorientation axes (between 2 and $10^{\circ}$ ). See caption of Fig. 7 for details.

crystals grown during retrograde $P-T$ conditions (in SE1369 and SE13-76) indicates that brittle deformation also persisted during cooling. This is further supported by the ubiquitous presence of wider epidote- and prehnite-filled fractures crosscutting the entire HT amphibolite (Fig. 2d).

The brittle behavior of amphibole within a rock deforming ductilely at high temperature has already been reported (Nyman et al., 1992; Berger and Stunitz, 1996; Imon et al., 2002; Diaz Aspiroz et al., 2007; Gomez Barreiro et al., 2010; Ko and Jung, 2015; Marti et al., 2017; Giuntoli et al., 2018) but ascribed to significantly lower deformation temperatures $\left(\leq 700^{\circ} \mathrm{C}\right)$. Preferential microfracturing along planes including the long ([001]) crystallographic axis could explain the similar aspect ratios of fine and coarse amphibole grains (essentially $\leq 2-3$, as suggested by Gomez Barreiro et al. (2010). Microfracturing along the [001] crystallographic axis together with small rigid rotations $\left(1-3^{\circ}\right.$; Fig. $\left.6 \mathrm{e}-\mathrm{h}\right)$ may further explain some of the apparent intracrystalline misorientations in amphibole around the [001] rotation axis (Figs. 6j, 8c)

Intense grain size reduction through brittle deformation in fact affected the whole rock at or near peak conditions as attested by the presence of fractured and rotated garnet and jadeite-rich clinopyroxene porphyroclasts in sample SE1367. The lack of microfractures in the new small clinopyroxene suggests that fracturing preferentially occurred along cleavage planes of the porphyroclasts, and the precipitation of minute amphibole along these cleavage planes has probably facilitated the failure. Moreover, the intense brittle deformation followed by small rigid rotation easily explained the general weak of the CPO of clinopyroxene in the amphibolite.
The strong correlation between the aspect ratio and the CPO and SPO intensities of primary and secondary amphibole in all samples (Fig. 10) also advocates for a component of rigid grain rotation in the strain accommodation from peak to retrograde conditions (as previously reported in other settings; Ildefonse et al., 1990; Shelley, 1994; Berger and Stünitz, 1996; Díaz Azpiroz et al., 2007; Tatham et al., 2008; Elyaszadeh et al., 2018). Contrary to clinopyroxene, the high aspect ratio of amphibole allowed the preferential alignment of the long axes parallel to the stretching direction. Yet, the strong SPO and CPO parallel to the lineation in secondary amphibole could also be explained by oriented dissolutionprecipitation during cooling conditions (e.g., Shelley, 1994; Berger and Stünitz, 1996).

\subsubsection{Dissolution-precipitation creep and grain boundary sliding}

Lobate boundaries and patchy zoning of amphibole defined by Ti-high cores truncated by the precipitation of Ti-medium to Ti-low areas reveal that brittle deformation was closely associated with and/or promoted dissolution and precipitation (Fig. $6 \mathrm{k}-\mathrm{m}$ ). This is also indicated by the nucleation of Ti-medium amphibole and jadeite-poor clinopyroxene within microfractures and cleavages of diopside-rich clinopyroxene (Figs. 5g, 7).

Dissolution-precipitation creep was likely driven by the metastability of the peak assemblage during cooling and hydration and was further enhanced by the permeability created by the microfracturing. Such a positive feedback between viscous and/or brittle deformation and (hydrous) mineral reactions was recently described in shear experiments on amphibolites conducted at $600-800^{\circ} \mathrm{C}$ and $0.5-1.5 \mathrm{GPa}$ (Marti et al., 2017, 2018). The tight relationship between brittle de- 


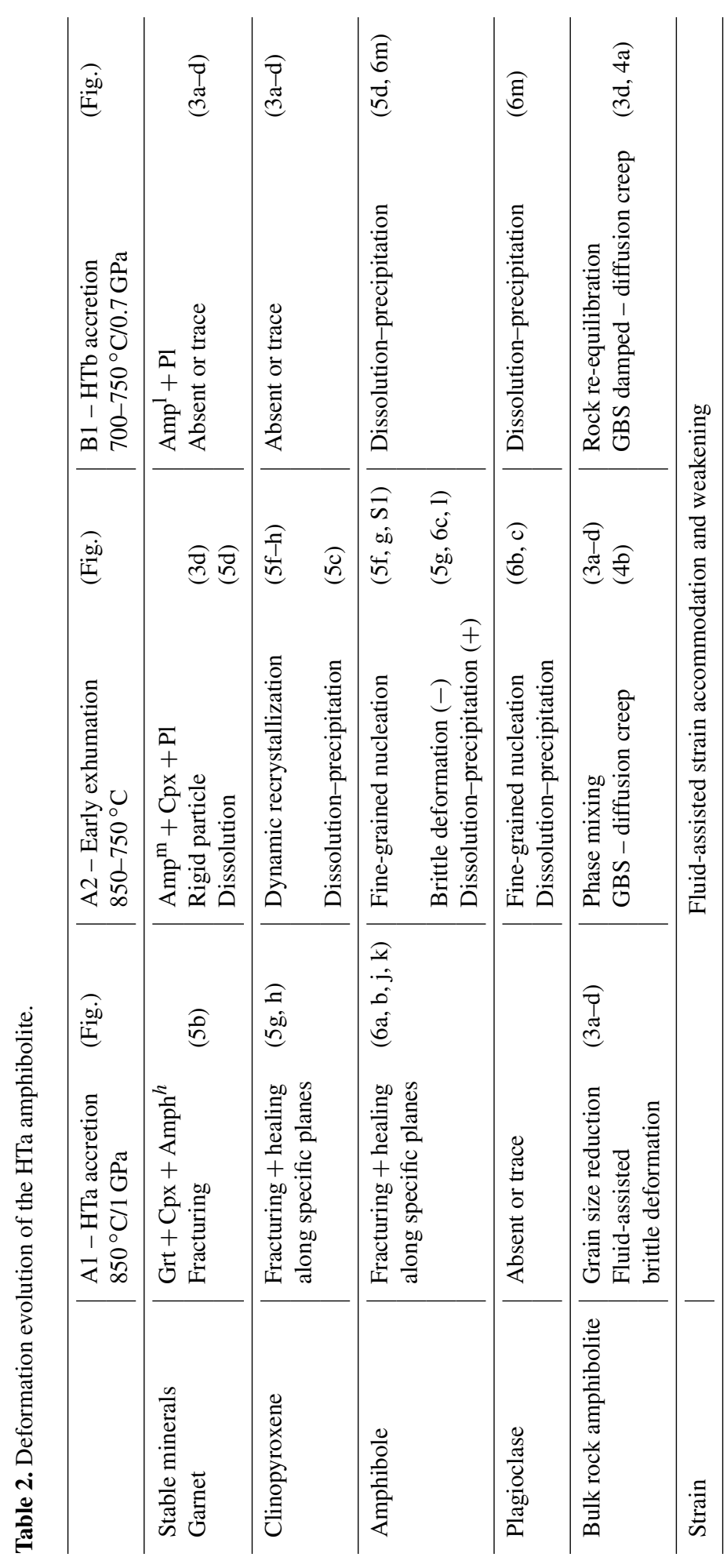

formation and dissolution-precipitation creep advocates for transient changes in pore-fluid pressure, either during dehydration (and/or melting) at peak conditions (e.g., Brodie and Rutter, 1985) or during the onset of retrogression (i.e., fluid ingression from adjacent slab dehydration; e.g., in a colder subduction context: Locatelli et al., 2018).

The presence of randomly oriented minute amphibole at the grain boundaries of mantled clinopyroxene and the general intense phase mixing in the polymineralic matrix testify to the activation of grain boundary sliding (GBS) as a dominant mechanism accompanying dissolution-precipitation creep syn to post grain size reduction, even in the monomineralic layers (A1; SE13-67). The absence, in the retrogressed HTa amphibolite (sample SE13-69; Fig. 3a), of microstructural evidence (e.g., pressure shadows) for any strength contrast between phases known to have different strength further supports the role of GBS.

\subsection{Mechanical evolution of the plate interface during subduction infancy}

During initial subduction progress, the leading edge of the slab encounters an increasingly warmer, anhydrous mantle wedge acting as a buttress (Fig. 14a; Agard et al., 2016). Accretion of metamorphic soles to the basal peridotites of the future ophiolite reflects this increased mechanical coupling between the plates across a restricted $P-T$ time window (i.e., when viscosities of the slab crust and overlying mantle are similar; Agard et al., 2016). Our microstructural data allow us to document the evolution of the deformation at the top of the slab (stages A1-A2-B; Figs. 13, 14):

- Approximatively from amphibolite to granulite facies and up to $850 \pm 50^{\circ} \mathrm{C}$ and $1.0 \mathrm{GPa}$, the slab crust progressively dehydrates and minerals such as amphibole (Ti-medium and Ti-poor) and plagioclase are replaced by mechanically stronger garnet and clinopyroxene in the HTa unit (and Ti-rich amphibole; stage A1; Fig. 13a). The leading edge of the slab thus likely hardens (as shown by the evolution of the strength curve in Fig. 14). When it reaches the strength of the mantle on top, HTa gets stripped and becomes the first slice accreted to the upper plate peridotite (stage A; Fig. 14). Our observations indicate that a strong amphibole fabric dominates rock anisotropy at the top of the slab. This fabric is controlled by syn-kinematic-oriented growth and rigid grain rotation, as shown by the strong correlation between grain size, aspect ratio and fabric intensity. The onset of brittle deformation in the garnetclinopyroxene amphibolite leads to drastic grain size reduction (GSR; stage A1; Fig. 13a). This brittle deformation, possibly controlled by dehydration embrittlement (Davies, 1999), dehydration-driven stress transfer (Ferrand et al., 2017) and/or fluid ingression from adjacent slab dehydration acts as a precursor for strain localization in the garnet-clinopyroxene amphibolite within 


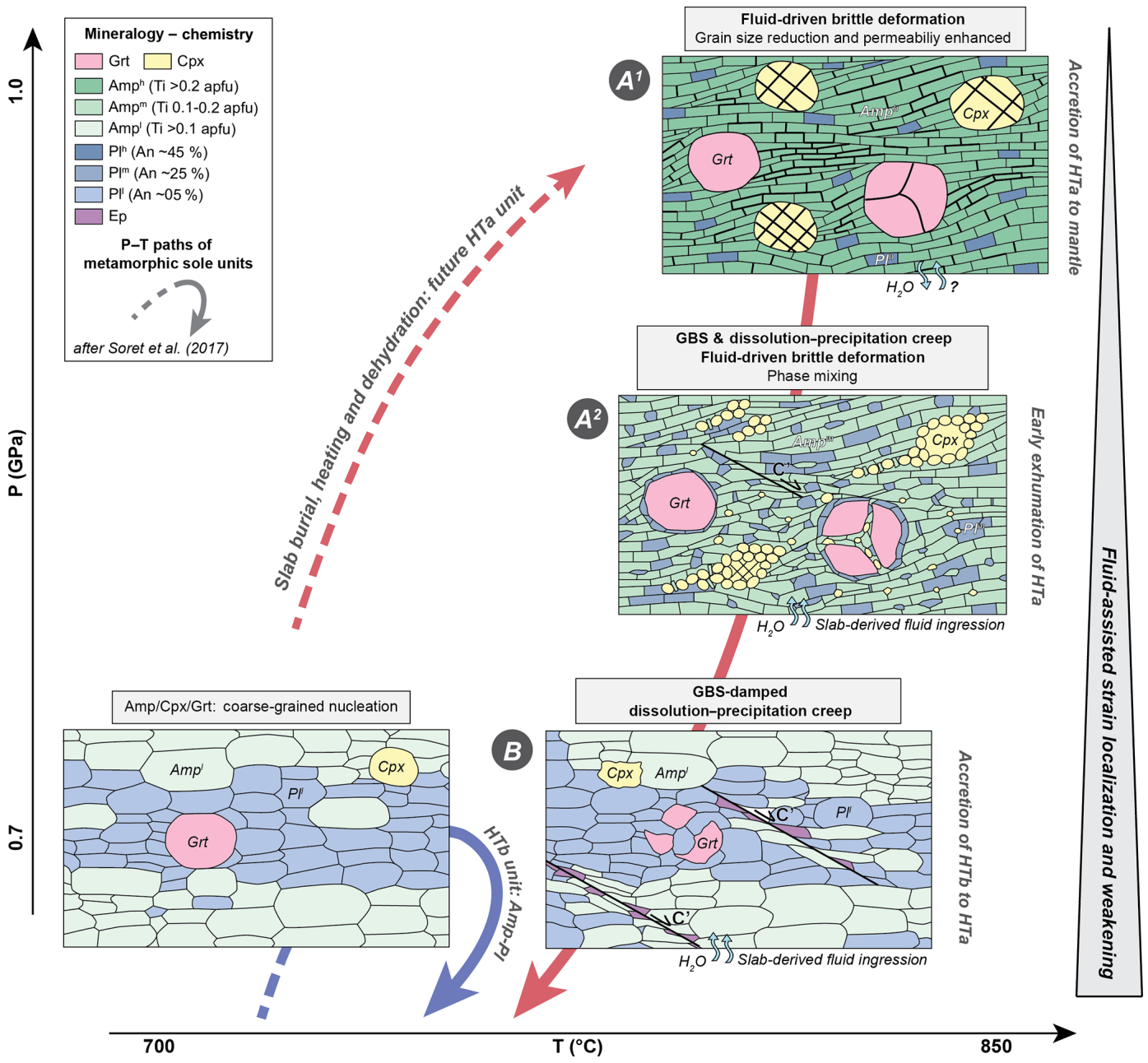

Figure 13. Model evolution at the grain scale of the deformation of the amphibolite of the Semail metamorphic sole (as a witness of that of the top of the slab crust during subduction infancy) during the formation, accretion and early exhumation to the peridotite during the subduction infancy.

the downgoing slab (and therefore detachment of HTa; Fig. 14). Similarly, fluids released at the plate interface during slab burial are thought to trigger early strain softening of the base of the mantle wedge through GSR promoted by fluid/mantle interaction and dissolutionprecipitation processes (Fig. 14b; Prigent et al., 2018b; Soret et al., 2016). Overall, these combined processes controlled the onset and location of strong mechanical coupling across the plate interface, between the top of the slab and the base of the nascent mantle wedge (stage A; Fig. 14).

- From 850 down to $750^{\circ} \mathrm{C}$ and 1 to $0.7 \mathrm{GPa}$ (stage A2 in Fig. 13a), early exhumation and cooling of the garnet-clinopyroxene-bearing $\mathrm{HTa}$ is associated with strong shearing and pervasive retrogression across the plate interface (Soret et al., 2017; Prigent et al., 2018b). Deformation in HTa is extensively accommodated by dissolution and precipitation assisted by grain bound- ary sliding (including mineral reactions, heterogeneous nucleation and phase mixing), leading to a second stage of significant strain softening of the exhuming HTa unit. Dissolution-precipitation creep and GBS are closely related to the brittle deformation events observed from peak conditions and operating until late exhumation (see Sect. 6.3) which facilitate fluid ingression and thereby enhanced mineral reactions and rock reequilibration within HTa. Syn-exhumation mechanical softening occurs also in the basal mantle wedge in the diffusion creep regime as it becomes colder and more metasomatized (Fig. 14; Agard et al., 2016; Prigent et al., 2018a, b; Soret et al., 2016). Similar weakening on both sides of the plate interface maintains a coupling between HTa and the peridotites and explains their coeval early exhumation (from $\sim 1$ to $0.7 \mathrm{GPa}$ ).

- At temperatures around $750^{\circ} \mathrm{C}$ (stage B: Figs. $12 \mathrm{~b} ; 14$ ), during later exhumation and cooling of $\mathrm{HTa}$, perva- 
Metamorphic sole (de)formation during subduction infancy

Stage A: (de)formation at $850^{\circ} \mathrm{C}$ and $1 \mathrm{GPa}$ (HTa accretion)

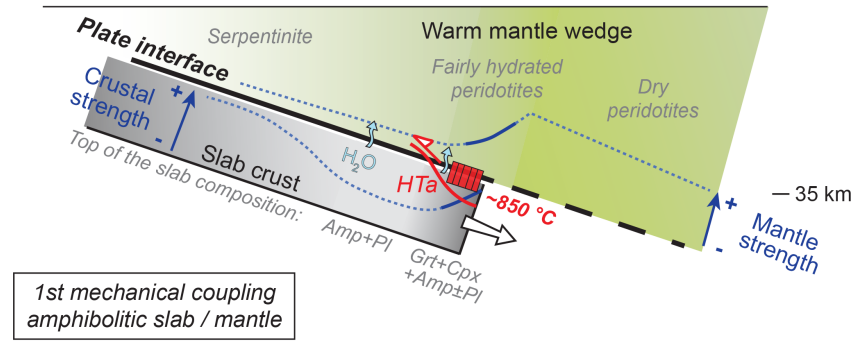

Stage B: (de)formation at $750{ }^{\circ} \mathrm{C}$ and $0.7 \mathrm{GPa}$ (HTb accretion)

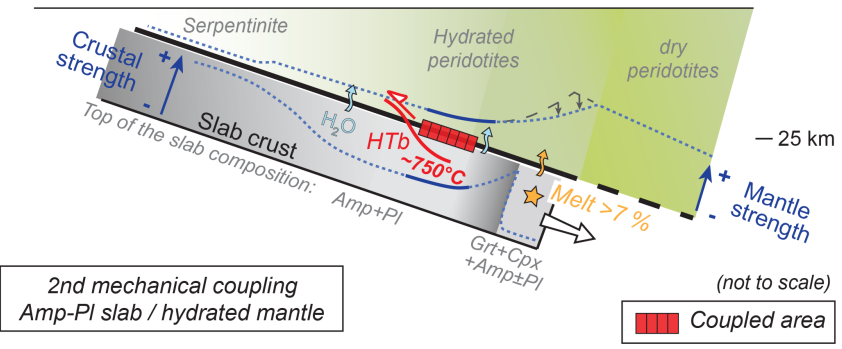

Figure 14. Schematic view of the strength evolution in the top of the slab crust and in the peridotite across the nascent subduction interface. Strong and transient interplate mechanical coupling allows the detachment and accretion of HTa and HTb metamorphic sole units to the peridotite (of the future ophiolite).

sive fluid-rock interaction transforms the base of HTa into a two-phase matrix composed of syn-kinematic Timedium to Ti-low amphibole and plagioclase, with only minor amounts of biotite and epidote. Meanwhile, the top of the subducting slab (i.e., the future plagioclaserich $\mathrm{HTb}$ unit) consists of a similar mineral assemblage (Fig. 14). Our observations show that GBS is progressively inhibited while dissolution-precipitation creep remains the dominant deformation mechanism, thus behaving potentially like the HTb unit. In the absence of significant GBS, the modal increase in (wet) plagioclase has a major softening effect. Mechanical coupling between $\mathrm{HTb}$ and HTa and/or HTb and the weakening at the base of the mantle wedge is responsible for the detachment and accretion of HTb (Fig. 14).

These deformation stages between 850 and $750{ }^{\circ} \mathrm{C}$ result in the extreme thinning and distribution of similar HT metamorphic soles below the ophiolite (shear strain $\geq 5$ ) and in the thinning of the base of the ophiolite itself (see discussion in Dewey and Casey, 2013).

\subsection{Mechanical implications for warm subduction zones and oceanic/continental crustal-scale shear zones}

We envision at least three major implications of this record of progressive deformation in metamorphic soles:
- Since pressure is not expected to significantly influence deformation mechanisms in the ductile regime, we argue that deep recoupling mechanisms in mature warm subduction zones (at $T \geq 800^{\circ} \mathrm{C}$; e.g., Nankai, Cascadia; Wada and Wang, 2009; Abers et al., 2017) could be controlled, as for HTa metamorphic soles, by the extent of fluid-rock interactions and the degree of stability of high-pressure amphibole.

- Dissolution-precipitation creep and associated amphibole-forming reactions coupled with brittle deformation may also control strain localization at high-temperature conditions, and therefore the development of long-lived oceanic detachments and core complexes in slow-spreading environments (Boschi et al., 2006; Escartin et al., 2003; Gülcher et al., 2019), as well as continental crustal-scale shear zones in collisional settings under cooling conditions and exhumation (Getsinger et al., 2013; Giuntoli et al., 2018; Tatham et al., 2008).

- Finally, while many different interpretations have been invoked for the deformation mechanisms of amphibole and amphibolites (e.g., GBS, diffusion creep, dislocation creep; see Sect. 2), such diversity could reflect changes in $P-T$ conditions, water activity and mineral stability. This study outlines that ongoing metamorphic processes and amphibole stability should be carefully taken into account when interpreting deformation mechanisms in amphibole, especially in shear zones experiencing hydration and cooling during exhumation, as a well-developed CPO in amphibole does not systematically testify to dislocation creep and does not exclude a component of fracturing and GBS in sheared amphibolites.

\section{Conclusions}

Based on microstructural analysis and mineral chemistry, this study highlights the mineral-scale mechanisms controlling the progressive deformation of sheared amphibolites from the Oman metamorphic sole during subduction infancy and unravels how strain is localized and accommodated in (hydrated) mafic rocks under amphibolite and granulite facies conditions. Metamorphic reactions and pore-fluid pressures driven by changes in $P-T$ conditions and/or water activity exert a key control on the rheology of mafic rocks and the transition between brittle and viscous deformations at hightemperature conditions (as noted experimentally; Marti et al., 2017, 2018).

At $850 \pm 50^{\circ} \mathrm{C}$ and $1 \mathrm{GPa}$, garnet-clinopyroxene amphibolites accommodate large shear strain essentially through fracturing, grain size reduction and grain boundary sliding, confirming that amphibole and amphibolite have only little ability to deform in the dislocation creep regime. The 
exact driving mechanism for the fracturing remains uncertain. Possible explanations include dehydration embrittlement, dehydration-driven stress transfer and/or fluid ingression.

Lower temperatures $\left(800-700^{\circ} \mathrm{C}\right)$ and higher hydrated conditions on the return path lead to higher rock disequilibrium and therefore pervasive hydrous reactions. Strain in the exhumed amphibolite is dominantly accommodated in the dissolution-precipitation creep regime assisted and enhanced by a component of brittle deformation. Grain size reduction through fracturing and heterogeneous nucleation enables GBS and significant phase mixing, thereby producing a large mechanical weakening. However, the fabric intensity of amphibole is not significantly affected by the GBS activation (contrary to clinopyroxene and plagioclase) due to its specific high aspect ratio.

These mechanical evolutions, marked by strain hardening during increasing $P-T$ conditions and dehydration and later large strain softening during cooling and hydration, are, respectively, coeval with the detachment and early exhumation of the different amphibolitic units of the HT metamorphic sole. They likely control the extent of the viscosity contrast and, therefore, the mechanical coupling between the top of the slab and the peridotites across the plate interface during subduction infancy (Agard et al., 2016; Prigent et al., 2018b).

As amphibole is commonly found with plagioclase, clinopyroxene and/or garnet in high-temperature shear zones, these largely pressure-independent findings may be applied to other geodynamic environments where similar temperatures, lithologies, fluid circulation and mechanical coupling between mafic rocks and peridotites prevail, such as in mature warm subduction zones (e.g., Nankai, Cascadia) in lower continental crust shear zones and oceanic detachments.

Data availability. The details of the EBSD and microprobe data are available either in Soret et al. (2017) (https://doi.org/10.1111/jmg.12267) or directly from the authors (Mathieu Soret and Philippe Agard) upon request (math.soret@gmail.com and philippe.agard@sorbonneuniversite.fr).

Supplement. The supplement related to this article is available online at: https://doi.org/10.5194/se-10-1733-2019-supplement.

Author contributions. MS, PA and BD conceived the initial idea of the study. MS, PA, BD and CP participated in the fieldwork. MS conducted EBSD and EMP (electron microprobe) analyses. MS and BI performed EBSD data processing using MTEX. MS prepared the manuscript with contributions from all co-authors.

Competing interests. The authors declare that they have no conflict of interest.
Acknowledgements. We thank Fabrice Barou (Université de Montpellier, France) for technical support on EBSD, Nicolas Rividi and Michel Fialin (CAMPARIS, Sorbonne University, Paris, France) for technical support on EMP, Christophe Nevado and Doriane Delmas (Université de Montpellier) for the polishing of thin sections, and Loïc Labrousse, Edwin Gnos, Philippe Yamato and Riccardo Graziani for helpful discussions.

Financial support. This research has been supported by the ANR blanche to Philippe Agard (ONLAP project, grant no. SIMI6 2010 BLAN 615 01) and the Marie Curie International Training Network (grant no. 604713). Additional support was provided by an IUF grant (Institut Universitaire de France) to Philippe Agard.

Review statement. This paper was edited by Patrice Rey and reviewed by Marco Herwegh and Vasileios Chatzaras.

\section{References}

Abers, G. A., Van Keken, P. E., and Hacker, B. R.: The cold and relatively dry nature of mantle forearcs in subduction zones, Nat. Geosci., 5, 333-337, https://doi.org/10.1038/ngeo2922 2017.

Agard, P., Yamato, P., Soret, M., Prigent, C., Guillot, S., Plunder, A., Chauvet, A., and Monié, P.: Plate interface rheological switches during subduction infancy: control on slab penetration and metamorphic sole formation, Earth Planet. Sc. Lett., 451, 208-220, https://doi.org/10.1016/j.epsl.2016.06.054 2016.

Agard, P., Plunder, A., Angiboust, S., Bonnet, G., and Ruh, J.: The subduction plate interface: Rock record and mechanical coupling (from long to short time scales), Lithos, 320/321, 537-566, https://doi.org/10.1016/j.lithos.2018.09.029, 2018.

Ambrose, T. K., Wallis, D., Hansen, L. N., Waters, D. J., and Searle, M. P.: Controls on the rheological properties of peridotite at a palaeosubduction interface: A transect across the base of the Oman-UAE ophiolite, Earth Planet. Sc. Lett., 491, 193-206, https://doi.org/10.1016/j.epsl.2018.03.027, 2018.

Bachmann, F., Hielscher, R., and Schaeben, H.: Texture Analysis with MTEX - Free and Open Source Software Toolbox, Sol. St. Phen., 160, 63-68, 2010.

Bascou, J., Tommasi, A., and Mainprice, D.: Plastic deformation and development of clinopyroxene lattice preferred orientations in eclogites, J. Struct. Geol., 24, 1357-1368, https://doi.org/10.1016/S0191-8141(01)00137-7, 2002.

Berger, A. and Stünitz, H.: Deformation mechanisms and reaction of hornblende: examples from the Bergell tonalite (Central Alps), Tectonophysics, 257, 149-174, https://doi.org/10.1016/00401951(95)00125-5, 1996.

Boschi, C., Früh-Green, G. L., Delacour, A., Karson, J. A., and Kelley, D. S.: Mass transfer and fluid flow during detachment faulting and development of an oceanic core complex, Atlantis Massif (MAR 30 N), Geochem. Geophy. Geosy., 7, Q01004, https://doi.org/10.1029/2005GC001074, 2006.

Boudier, F., Ceuleneer, G., and Nicolas, A.: Shear zones, thrusts and related magmatism in the Oman ophiolite: Initiation of thrusting on an oceanic ridge, Tectonophysics, 151, 275-296, https://doi.org/10.1016/0040-1951(88)90249-1. 1988. 
Brodie, K. H.: Variation in amphibole and plagioclase composition with deformation, Tectonophysics, 78, 385-402, https://doi.org/10.1016/0040-1951(81)90021-4, 1981.

Brodie, K. H. and Rutter, E. H.: On the relationship between rock deformation and metamorphism with special reference to the behaviour of basic rocks, Metamorphic Reactions, 4, 138-179, https://doi.org/10.1007/978-1-4612-5066-1_6, 1985.

Bunge, H. J.: Texture Analysis in Materials Science, Butterworth's, London, 351-401, 1982.

Bystricky, M. and Mackwell, S.: Creep of dry clinopyroxene aggregates, J. Geophys. Res., 106, 13443, https://doi.org/10.1029/2001JB000333, 2001.

Cao, S., Liu, J., and Leiss, B.: Orientation-related deformation mechanisms of naturally deformed amphibole in amphibolite mylonites from the Diancang Shan, SW Yunnan, China, J. Struct. Geol., 32, 606-622, https://doi.org/10.1016/j.jsg.2010.03.012, 2010.

Davies, H. L.: The role of hydraulic fractures and intermediatedepth earthquakes in generating subduction-zone magmatism, Nature, 328, 142-145, https://doi.org/10.1038/18202, 1999.

Dewey, J. F. and Casey, J. F.: The sole of an ophiolite: the Ordovician Bay of Islands Complex, Newfoundland, J. Geol. Soc. London, 170, 715-722, https://doi.org/10.1144/jgs2013-017, 2013.

Díaz Aspiroz, M., Lloyd, G. E., and Fernández, C.: Development of lattice preferred orientation in clinoamphiboles deformed under low-pressure metamorphic conditions, A SEM/EBSD study of metabasites from the Aracena metamorphic belt (SW Spain), J. Struct. Geol., 29, 629-645, https://doi.org/10.1016/j.jsg.2006.10.010 2007

Dimanov, A., Rybacki, E., Wirth, R., and Dresen, G.: Creep and strain-dependent microstructures of synthetic anorthitediopside aggregates, J. Struct. Geol., 29, 1049-1069, https://doi.org/10.1016/j.jsg.2007.02.010, 2007.

Elyaszadeh, R., Prior, D. J., Sarkarinejad, K., and Mansouri, H.: Different slip systems controlling crystallographic preferred orientation and intracrystalline deformation of amphibole in mylonites from the Neyriz mantle diapir, Iran. J. Struct. Geol., 107, 38-52, https://doi.org/10.1016/j.jsg.2017.11.020, 2018.

Ernst, W. and Liu, J.: Experimental phase-equilibrium study of Al-and Ti-contents of calcic amphibole in MORB - A semiquantitative thermobarometer, Am. Mineral., 83, 952-969, https://doi.org/10.2138/am-1998-9-1004, 1998.

Escartín, J., Mével, C., MacLeod, C. J., and McCaig, A. M.: Constraints on deformation conditions and the origin of oceanic detachments: The Mid-Atlantic Ridge core complex at $15^{\circ} 45^{\prime} \mathrm{N}$, Geochem. Geophy. Geosy., 4, 1067, https://doi.org/10.1029/2002GC000472, 2003.

Ferrand, T. P., Hilairet, N., Incel, S., Deldicque, D., Labrousse, L., Gasc, J., Renner, J., Wang, Y., Green II, H. W., and Schubnel, A.: Dehydration-driven stress transfer triggers intermediate-depth earthquakes, Nat. Commun., 8, 1-11, https://doi.org/10.1038/ncomms15247, 2017.

Frets, E., Tommasi, A., Garrido, C. J., Padrón-navarta, J. A., and Amri, I.: Deformation processes and rheology of pyroxenites under lithospheric mantle conditions, J. Struct. Geol., 39, 138-157, https://doi.org/10.1016/j.jsg.2012.02.019, 2012.

Getsinger, A. J.: The Rheology of Amphibolite, Brown University, Ph.D. Thesis, 187 pp., 2015.
Getsinger, A. J. and Hirth, G.: Amphibole fabric formation during diffusion creep and the rheology of shear zones, Geology, 42, 535-538, https://doi.org/10.1130/G35327.1, 2014.

Getsinger, A. J., Hirth, G., Stünitz, H., and Goergen, E. T.: Influence of water on rheology and strain localization in the lower continental crust, Geochem. Geophy. Geosy., 14, 2247-2264, https://doi.org/10.1002/ggge.20148, 2013.

Giuntoli, F., Menegon, L., and Warren, C. J.: Replacement reactions and deformation by dissolution and precipitation processes in amphibolites, J. Metamorph. Geol., 36, 1263-1286, https://doi.org/10.1111/jmg.12445, 2018.

Gnos, E.: Peak Metamorphic Conditions of Garnet Amphibolites Beneath the Semail Ophiolite: Implications for an Inverted Pressure Gradient, Int. Geol. Rev., 40, 281-304, https://doi.org/10.1080/00206819809465210, 1998.

Gómez Barreiro, J., Martínez Catalán, J. R., Prior, D., Wenk, H. -R., Vogel, S., Díaz García, F., Arenas, R., Sanchez Martinez, S., and Lonardelli, I.: Fabric Development in a Middle Devonian Intraoceanic Subduction Regime: The Careón Ophiolite (Northwest Spain), J. Geol., 118, 163-186, doi.org/10.1086/649816, 2010.

Gray, D. R. and Gregory, R. T.: Implications of the structure of the Wadi Tayin metamorphic sole, the Ibra-Dasir block of the Samail ophiolite, and the Saih Hatat window for late stage extensional ophiolite emplacement, Oman. Mar. Geophys. Res., 21, 211-227, https://doi.org/10.1023/A:1026772717865, 2000.

Guilmette, C., Smit, M. A., Hinsbergen, D. J. J. Van, Gürer, D., Corfu, F., Charette, B., Maffione, M., Rabeau, O., and Savard, D.: Forced subduction initiation recorded in the sole and crust of the Semail Ophiolite of Oman, Nat. Geosci., 11, 688-695, https://doi.org/10.1038/s41561-018-0209-2, 2018.

Gülcher, A. J. P., Beaussier, S. J., and Gerya, T. V.: On the formation of oceanic detachment faults and their influence on intra-oceanic subduction initiation: 3D thermomechanical modeling, Earth Planet. Sc. Lett., 506, 195-208, https://doi.org/10.1016/j.epsl.2018.10.042, 2019.

Hacker, B. R.: Simulation of the metamorphic and deformational history of the metamorphic sole of the Oman ophiolite, J. Geophys. Res.-Sol. Ea., 95, 4895-4907, https://doi.org/10.1029/JB095iB04p04895, 1990.

Hacker, B. R. and Christie, J. M.: Brittle/Ductile and Plastic/Cataclastic Transitions in Experimentally Deformed and Metamorphosed Amphibolite, Geoph. Monog. Series., 56, 127 148, https://doi.org/10.1029/GM056p0127, 1990.

Hielscher, R. and Schaeben, H.: A novel pole figure inversion method: Specification of the MTEX algorithm, J. Appl. Crystall., 41, 1024-1037, https://doi.org/10.1107/S0021889808030112, 2008.

Hier-Majumder, S., Mei, S., and Kohlstedt, D. L.: Water weakening of clinopyroxenite in diffusion creep, J. Geophys. Res.-Sol. Ea., 110, 1-12, https://doi.org/10.1029/2004JB003414, 2005.

Ildefonse, B., Lardeaux, J. M., and Caron, J. M.: The behavior of shape preferred orientations in metamorphic rocks: amphiboles and jadeites from the Monte Mucrone area (Sesia-Lanzo zone, Italian Western Alps), J. Struct. Geol., 12, 1005-1011, https://doi.org/10.1016/0191-8141(90)90096-H, 1990.

Ildefonse, B., Sokoutis, D., and Mancktelow, N. S.: Mechanical interactions between rigid particles in a deforming ductile matrix. Analogue experiments in simple shear flow, J. Struct. Geol., 
14, 1253-1266, https://doi.org/10.1016/0191-8141(92)90074-7, 1992.

Imon, R., Okudaira, T., and Kanagawa, K.: Development of shapeand lattice-preferred orientations of amphibole grains during initial cataclastic deformation and subsequent deformation by dissolution-precipitation creep in amphibolites from the Ryoke metamorphic belt, SW Japan, J. Struct. Geol., 26, 793-805, https://doi.org/10.1016/j.jsg.2003.09.004, 2004.

Ingrin, J., Doukhan, N., and Doukhan, J. C.: High-Temperature Deformation of Diopside Single-Crystal, 2. Transmission Electron-Microscopy Investigation Of The Defect Microstructures, J. Geophys. Res.-Solid, 96, 14287-14297, https://doi.org/10.1029/91JB01233, 1991.

Ji, S., Shao, T., Michibayashi, K., Long, C., Wang, Q., Kondo, Y., Zhao, W., Wang, H., and Salisbury, M. H.: A new calibration of seismic velocities, anisotropy, fabrics, and elastic moduli of amphibole-rich rocks, J. Geophys. Res.-Sol. Ea., 118, 46994728, https://doi.org/10.1002/jgrb.50352, 2013.

Kim, D., Katayama, I., Wallis, S., Michibayashi, K., Miyake, A., Seto, Y., and Azuma, S.: Deformation microstructures of glaucophane and lawsonite in experimentally deformed blueschists: Implications for intermediate-depth intraplate earthquakes, J. Geophys. Res.-Sol. Ea., 120, 1229-1242. https://doi.org/10.1002/2014JB011528 2015.

Ko, B. and Jung, H.: Crystal preferred orientation of an amphibole experimentally deformed by simple shear, Nat. Commun., 6, 6586, https://doi.org/10.1038/ncomms7586, 2015.

Kruse, R. and Stünitz, H.: Deformation mechanisms and phase distribution in mafic high-temperature mylonites from the Jotun Nappe, southern Norway, Tectonophysics, 303, 223-249, 1999.

Lloyd, G. E., Farmer, A. B., and Mainprice, D.: Misorientation analysis and the formation and orientation of subgrain and grain boundaries, Tectonophysics, 279, 55-78, https://doi.org/10.1016/S0040-1951(97)00115-7, 1997.

Locatelli, M., Verlaguet, A., Agard, P., Federico, L., and Angiboust, S.: Intermediate-depth brecciation along the subduction plate interface (Monviso eclogite, W. Alps), Lithos, 320/321, 378-402, https://doi.org/10.1016/j.lithos.2018.09.028, 2018.

Lloyd, G. E., Butler, R. W. H., Casey, M., Tatham, D. J., and Mainprice, D.: Constraints on the seismic properties of the middle and lower continental crust, Geol. Soc. Spec. Publ., 360, 7-32, https://doi.org/10.1144/SP360.2, 2011.

Mainprice, D. and Nicolas, A.: Development of shape and lattice preferred orientations: application to the seismic anisotropy of the lower crust, J. Struct. Geol., 11, 175-189, https://doi.org/10.1016/0191-8141(89)90042-4, 1989.

Mainprice, D., Bachmann, F., Hielscher, R., and Schaeben, H.: Descriptive tools for the analysis of texture projects with large datasets using MTEX: strength, symmetry and components, Geol. Soc. Spec. Publ., 409, 251-271, https://doi.org/10.1144/SP409.8, 2014.

Marti, S., Stünitz, H., Heilbronner, R., Plümper, O., and Drury, M.: Experimental investigation of the brittle-viscous transition in mafic rocks - Interplay between fracturing, reaction, and viscous deformation, J. Struct. Geol., 105, 62-79, https://doi.org/10.1016/j.jsg.2017.10.011, 2017.

Marti, S., Stünitz, H., Heilbronner, R., Plümper, O., and Kilian, R.: Syn-kinematic hydration reactions, grain size reduction, and dissolution - precipitation creep in experimentally de- formed plagioclase - pyroxene mixtures, Solid Earth, 9, 9851009, https://doi.org/10.5194/se-9-985-2018, 2018.

Nicolas, A., Boudier, F., Ildefonse, B., and Ball, E.: Accretion of Oman and United Arab Emirates ophiolite - Discussion of a new structural map, Mar. Geophys. Res., 21, 147-179, https://doi.org/10.1023/A:1026769727917, 2000.

Nyman, M. W., Law, R. D., and Smelik, E. A.: Cataclastic deformation for the development of core mantle structures in amphibole, Geology, 20, 455-4458, 1992.

Plunder, A., Agard, P., Chopin, C., Soret, M., Okay, A. I., and Whitechurch, H.: Metamorphic sole formation, emplacement and blueschist facies overprint: early subduction dynamics witnessed by western Turkey ophiolites, Terra Nova, 28, 329-339, doi.org:10.1111/ter.12225, 2016.

Prigent, C., Guillot, S., Agard, P., Lemarchand, D., Soret, M., and Ulrich, M.: Transfer of subduction fluids into the deforming mantle wedge during nascent subduction: Evidence from trace elements and boron isotopes (Semail ophiolite, Oman), Earth Planet. Sc. Lett., 484, 213-228, doi.org:10.1016/j.epsl.2017.12.008, 2018a.

Prigent, C., Guillot, S., Agard, P., and Ildefonse, B.: FluidAssisted Deformation and Strain Localization in the Cooling Mantle Wedge of a Young Subduction Zone (Semail Ophiolite), J. Geophys. Res.-Sol. Ea., 123, 7529-7549, https://doi.org/10.1029/2018JB015492, 2018 b.

Prigent, C., Agard, P., Guillot, S., Godard, M., and Dubacq, B.: Mantle wedge deformation during subduction infancy: evidence from the base of the Semail ophiolitic mantle, J. Petrol., 59, 2061-2092, https://doi.org/10.1093/petrology/egy090, $2018 \mathrm{c}$.

Rioux, M., Garber, J., Bauer, A., Bowring, S., Searle, M., Kelemen, P., and Hacker, B.: Synchronous formation of the metamorphic sole and igneous crust of the Semail ophiolite: New constraints on the tectonic evolution during ophiolite formation from highprecision U-Pb zircon geochronology, Earth Planet. Sc. Lett., 451, 185-195, https://doi.org/10.1016/j.epsl.2016.06.051, 2016.

Rybacki, E. and Dresen, G.: Deformation mechanism maps for feldspar rocks, Tectonophysics, 382, 173-187, https://doi.org/10.1016/j.tecto.2004.01.006, 2004.

Schmidt, N.-H. and Olesen, N.: Computer-aided determination of crystal-lattice orientation from electron-channeling patterns in the SEM, Can. Mineral., 27, 15-22, 1989.

Shelley, D.: Spider texture and amphibole preferred orientations, J. Struct. Geol., 16, 709-717, https://doi.org/10.1016/01918141(94)90120-1, 1994.

Siegesmund, S., Helming, K., and Kruse, R.: Complete texture analysis of a deformed amphibolite: comparison between neutron diffraction and U-stage data, J. Struct. Geol., 16, 131-142, https://doi.org/10.1016/0191-8141(94)90024-8, 1994.

Soret, M., Agard, P., Dubacq, B., Vitale-Brovarone, A., Monié, P., Chauvet, A., Whitechurch, H., and Villemant, B.: Strain localization and fluid infiltration in the mantle wedge during subduction initiation: Evidence from the base of the New Caledonia ophiolite, Lithos, 244, 1-19, https://doi.org/10.1016/j.lithos.2015.11.022, 2016.

Soret, M., Agard, P., Dubacq, B., Plunder, A., and Yamato, P.: Petrological evidence for stepwise accretion of metamorphic soles during subduction infancy (Semail ophiolite, Oman and UAE), J. Metamorph. Geol., 35, 1050-1080, https://doi.org/10.1111/jmg.12267, 2017. 
Tatham, D. J., Lloyd, G. E., Butler, R. W. H., and Casey, M.: Amphibole and lower crustal seismic properties, Earth Planet. Sc. Lett., 267, 118-128, https://doi.org/10.1016/j.epsl.2007.11.042, 2008.

Wada, I. and Wang, K.: Common depth of slab-mantle decoupling: Reconciling diversity and uniformity of subduction zones, Geochem. Geophy. Geosy., 10, Q10009, https://doi.org/10.1029/2009GC002570, 2009.

Wakabayashi, J. and Dilek, Y.: Spatial and temporal relationships between ophiolites and their metamorphic soles: A test of models of forearc ophiolite genesis, Geol. Soc. Am. Spec. Publ., 349, 53-64, https://doi.org/10.1130/0-8137-2349-3.53, 2000.

Wakabayashi, J. and Dilek, Y.: What constitutes "emplacement" of an ophiolite?: Mechanisms and relationship to subduction initiation and formation of metamorphic soles, Geol. Soc. Am. Spec. Publ., 218, 427-447, https://doi.org/10.1144/GSL.SP.2003.218.01.22, 2003.
Wenk, H. R. and Christie, J. M.: Comments on the interpretation of deformation textures in rocks, J. Struct. Geol., 13, 1091-1110, https://doi.org/10.1016/0191-8141(91)90071-P, 1991.

Wheeler, J., Prior, D., Jiang, Z., Spiess, R., and Trimby, P.: The petrological significance of misorientations between grains, Contrib. Mineral. Petr., 141, 109-124, https://doi.org/10.1007/s004100000225, 2001.

Whitney, D. L. and Evans, B. W.: Abbreviations for names of rock-forming minerals, Am. Mineral., 95, 185-187, https://doi.org/10.2138/am.2010.3371, 2010. 